\title{
Tritium Concentrations in the F- and H-Area Seeplines and the Fourmile Branch at SRS: March and August 1998 Events and 1989-1998 Summary
}

by

J. Koch

RECORDS ADMINISTRATION

Westinghouse Savannah River Company

Savannah River Site

Aiken, South Carolina 29808

This paper was prepared in connection with work done under the above contract number with the U.S. Department of Energy. By acceptance of this paper, the publisher and/or recipient acknowledges the U. S. Government's right to retain a nonexclusive, royalty-free license in and to any copyright covering this paper, along with the right to reproduce and to authorize others to reproduce all or part of the copyrighted paper. 
WSRC-TR-99-00028

January 19, 1999

.

\section{Tritium Concentrations in the $\mathrm{F}$ - and $\mathrm{H}$-Area Seeplines and Fourmile Branch at SRS: March and August 1998 Events and 1989-1998 Summary (U).}

Prepared by: J. W. Koch II

Environmental Analysis Section

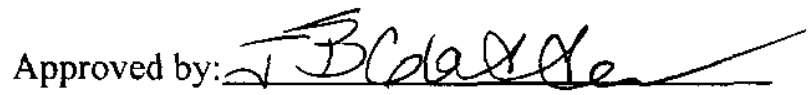

J.B. Gladden, Section Manager

Environmental Analysis Section

Westinghouse Savannah River Company

Savannah River Site

Aiken SC 29808

Prepared for the U. S. Department of Energy under contract number DE-AC09-96SR18500 


\section{DISCLAIMER}

This report was prepared as an account of work sponsored by an agency of the United States Government. Neither the United States Government nor any agency thereof, nor any of their employees, makes any warranty, express or implied, or assumes any legal liability or responsibility for the accuracy, completeness, or usefulness of any information, apparatus, product, or process disclosed, or represents that its use would not infringe privately owned rights. Reference herein to any specific commercial product, process, or service by trade name, trademark, manufacturer, or otherwise does not necessarily constitute or imply its endorsement, recommendation, or favoring by the United States Government or any agency thereof. The views and opinions of authors expressed herein do not necessarily state or reflect those of the United States Government or any agency thereof.

This report has been reproduced directly from the best available copy.

Available to DOE and DOE contractors from the Office of Scientific and Technical Information, P.O. Box 62, Oak Ridge, TN 37831; prices available from (615) 576-8401.

Available to the public from the National Technical Information Service, U.S. Department of Commerce, 5285 Port Royal Road, Springfield, VA 22161. 
WSRC-TR-99-00028

January 19, 1999

\section{Tritium Concentrations in the F- and H-Area Seeplines and Fourmile Branch at SRS: March and August 1998 Events and 1989-1998 Summary (U).}

Prepared by: J. W. Koch II

Prepared for the U. S. Department of Energy under contract no. DE-AC09-96SR18500 
This page is intentionally blank 


\section{TABLE OF CONTENTS}

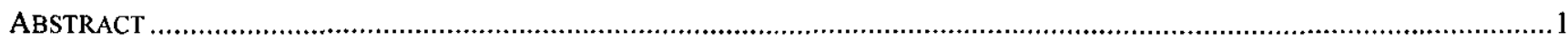

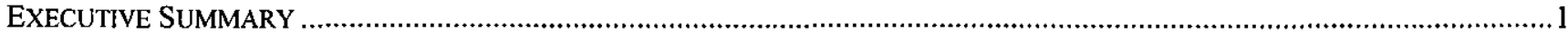

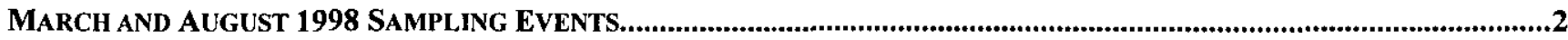

INTRODUCTION

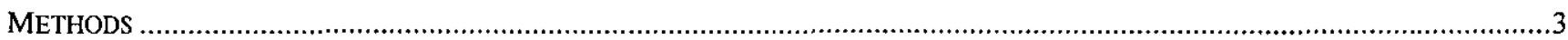

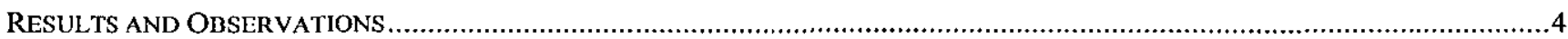

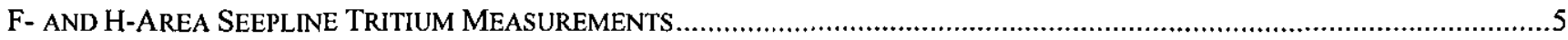

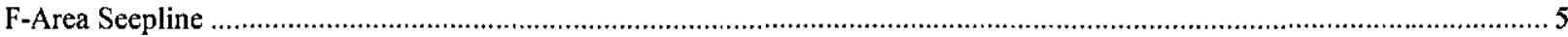

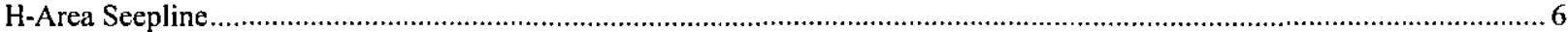

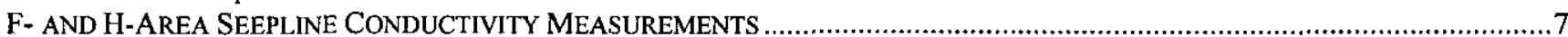

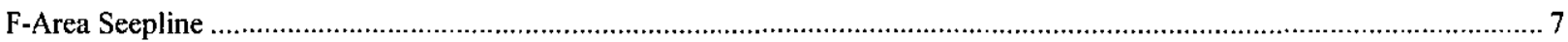

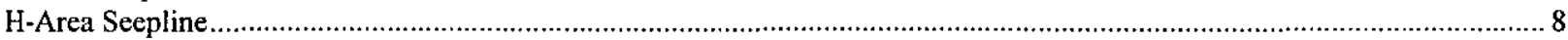

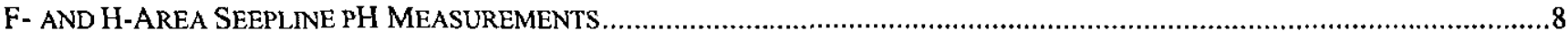

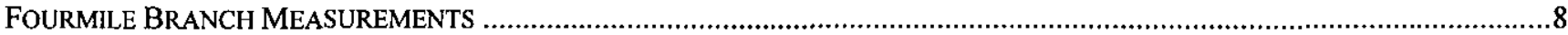

SOLID WASTE DISPOSAL FACILITY (643-E) SEEPLINE MEASUREMENTS ......................................................................

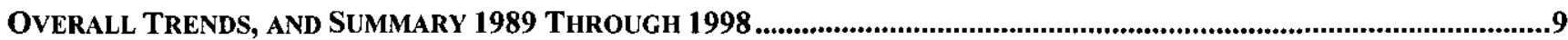

F-Area Seepline

H-Area Seepline

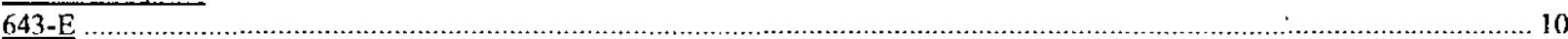

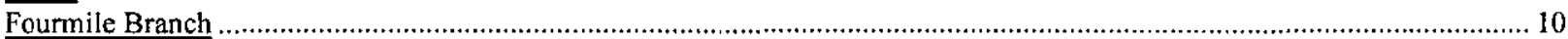

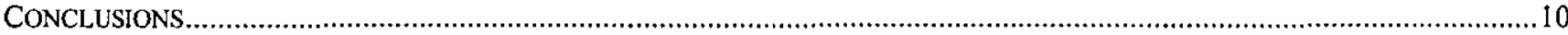

$\mathrm{F}$ - and H-Area Seeplines, and Fourmile Branch

Solid Waste Disposal Facility (643-E) Seepline

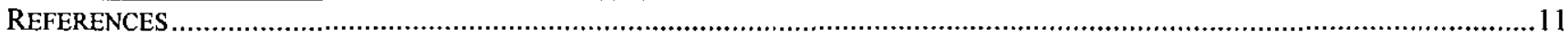




\section{LIST OF FIGURES}

Figure 1

Location of F-Area Seepage Basins and Seepline Sampling Points

Figure 2

Tritium Concentration for F-Area Seepline (1989-1998)

Figure 3

Location of H-Area Seepage Basins, Seepline Sampling Locations,

and Sampling Locations below 643-E

Figure 4

Tritium Concentration for H-Area Seepline (1989-1998)

Figure 5

Flow Schematic with Capped Seepagc Basins

Figure 6

Flow Schematic during Seepage Basin Operation

Figure 7

Diagram of the Tritium Plumes Migrating from F- and H-Area Seepage Basins

Figure 8

Comparison of Monthly Rainfall to the Long Term Average (1961-1994)

Figure 9

Comparison of Tritium Concentrations for F-Area Seepline Locations

Figure 10

Comparison of Tritium Measurements for H-Area Seepline Locations

Figure 11

Comparison of Conductivity Measurements for F-Area Seepline Locations

Figure 12

Comparison of Conductivity Measurements for $\mathrm{H}$-Area Seepline Locations

Figure 13

Comparison of $\mathrm{pH}$ Measurements for F-Area Seepline Locations

Figure 14

Comparison of $\mathrm{pH}$ Measurements for H-Area Seepline Locations

Figure 15

Comparison of Tritium Concentrations for Fourmile Branch Locations

Figure 16

Comparison of Conductivity Measurements for Fourmile Branch Locations

Figure 17

Comparison of $\mathrm{pH}$ Measurements for Fourmile Branch Locations

Figure 18

Comparison of Tritium Concentrations for Seepline below 643-E

Figure 19

Comparison of Conductivity Measurements for Seepline below 643-E

Figure 20

Comparison of $\mathrm{pH}$ Measurements for Seepline below 643-E

Figure 21

Tritium and Conductivity Trends for F-Area Seepline (1989-1998)

Figure 22

Tritium and Conductivity Trends for H-Area Seepline (1989-1998)

Figure 23

pH Trends for F-Area and H-Area Seeplines (1989-1998)

Figure 24

Comparison of Tritium concentrations for Seepline below 643-E (1992-1998) 


\section{List of Figures (cont'd)}

Figure 25

Figure 26

Figure 27
Tritium trends along Fourmile Branch sample locations (FMC001H, FMC002H, and FMC001F).

26 Conductivity trends along Fourmile Branch sample locations

(FMC001H, FMC002H, and FMC001F). 26

pH trends along Fourmile Branch sample locations (FMC001H, FMC002H, and FMC001F).
Note: $\quad$ Figures 8 through 20 show the results from the March 1998 and August 1998 sampling events.

Figures 2, 4, and 21 through 27 show overall summary results (1989-1998). 


\section{List of Tables}

Table la Wilcoxon Signed-Rank Test Comparisons, F-Area Seepline, March 1998 vs. 1989-1997

Table 1b

Wilcoxon Signed-Rank Test Comparisons, F-Area Seepline, August 1998 vs. 1989-1998

Table 2a Wilcoxon Signed-Rank Test Comparisons, H-Area Seepline, March 1998 vs. 1989-1997

Table 2b Wilcoxon Signed-Rank Test Comparisons, H-Area Seepline, August 1998 vs. 1989-1998

Table 3 Comparison of Monthly Rainfall to the Long Term Average

Table 4 Comparison of F-Area Seepline Measurements for Tritium, Conductivity, and pH for March 1989, March 1998, and September 1998 Sampling Events

Table 5 Comparison of H-Area Seepline Measurements for Tritium, Conductivity, and $\mathrm{pH}$ for March 1989, March 1998, and September 1998 Sampling Events

Table 6 Comparison of Fourmile Branch Stream Measurements for Tritium, Conductivity and $\mathrm{pH}$ for March 1989, March 1998, and September 1998 Sampling Events

Table 7 Comparison of 643-E Seepline Measurements for Tritium, Conductivity, and pH for March 1989, March 1998, and September 1998 Sampling Events

Table 8

Average Tritium, Conductivity, and $\mathrm{pH}$ Values for $\mathrm{F}$ - and $\mathrm{H}$-Area Seeplines (1989-1998)

Table 9 Average Tritium and Conductivity, and pH Values for Seepline Below 643-E (1992-1998)

Table 10

Tritium Concentrations for Fourmile Branch (1992-1998)

Table 11

Sample Collection Summary for F-Area Seepline (1989-1998)

Table 12

Sample Collection Summary for H-Area Seepline (1989-1998)

Table 13

Sample Collection Summary for 643-E Seepline (1992-1998)

Note: Tables 1 through 7 contain the March and August 1998 sampling event results.

Tables 8 through 13 contain overall trending comparisons for all sampling events (1989-1998). 


\title{
Tritium Concentrations in the F- and H-Area Seeplines and Fourmile Branch at SRS: March and August 1998 and March 1989-1998 Summary
}

\author{
J.W. Koch II
}

\begin{abstract}
The Environmental Analysis Section (EAS) of the Savannah River Technology Center (SRTC) conducted a quarterly monitoring program of the Fourmile Branch (FMB) stream and its associated seepline located down gradient from the F- and H-Area Seepage Basins from May 1992 to May 1995. The quarterly tritium survey was changed to a semi-annual schedule in 1996. This report presents the results of both semi-annual events conducted during 1998 and summarizes tritium data beginning with the 1989 and 1992 baseline sampling events. The primary focus of this program is to measure and track changes in tritium concentrations. Specific electrical conductivity and $\mathrm{pH}$ were also measured. The results from these surveys (March and August 1998) exhibited similar trends to data from the previous surveys. The results of these tritium surveys and stream monitoring data (Looney et al., 1993) indicated that the tritium plume from the past operation of the seepage basins continues to flush from the seeplines and wetlands to Fourmile Branch. The overall summary (1989-1998) indicates that the tritium plumes are surfacing in somewhat localized areas along the F-Area and 643-E seeplines. The tritium plume is surfacing more generally throughout the H-Area seepline.
\end{abstract}

\section{Executive Summary}

In March and August 1998 the Environmental Analysis Section (EAS) surveyed the Fourmile Branch seepline down gradient from the F- and $\mathrm{H}$ Area Seepage Basins for tritium, specific conductivity, and $\mathrm{pH}$. These surveys were the two semi-annual surveys scheduled during FY98 to monitor the movement of contaminants from the basins since their closure in 1990. Surface-water samples were collected at 58 of 63 planned locations along the secplines during March and 50 of 63 planned locations during August. The planned samples included three stream samples along Fourmile Branch during each event. The seepline locations included 22 from the F-Area seepline, 22 from the H-Area seepline, and 16 from the seepline south of 643-E, which is a decommissioned area in the Solid Waste Disposal Facility. Five of the planned sample locations were dry during the March 1998 event (two along the H-Area seepline and three from the seepline south of 643-E). During the August event thirteen of the planned locations were dry. Six of these were along the F-Area seepline, six were along the H-Area seepline and one was from the seepline south of 643-E. It was unusual to have this many dry sites in F-Area. Only the September 1997 event had more dry sampling locations (twenty-five).

Forty-four of the locations were sampled in 1989 (22 along the F-Area seepline and 22 along the HArea seepline) by the Savannah River Technology Center as part of an extensive characterization study (Haselow et al. 1990). Tritium activities along the FArea and $\mathrm{H}$-Area seeplines in March and August 1998 sampling events were significantly lower than the activities measured by Haselow et al. (1990). Taking comparisons a step further, in March and August 1998, tritium concentrations at the H-Area seepline were significantly lower than the first twelve sampling events, including the December 1994 sampling event. The H-Area seepline has 
shown a much greater decrease in tritium concentrations than the F-Area seepline. There were four locations from the March 1998 survey that showed an increase in tritium activity greater than $10 \%$ above the March 1989 results and five from the August 1998 survey. Conductivity measurements exhibited the same trends as tritium activities in the F-Area and H-Area seeplines for both surveys.

The average H-Area seepline water $\mathrm{pH}$ for the March and August 1998 sampling events was 5.7, which is slightly lower than the previous three surveys (6.0). The average F-Area seepline water $\mathrm{pH}$ was 4.9 for both the March and August 1998 sampling events. This was slightly lower than the September 1997 survey (5.2). These results continue to indicate conditions have somewhat stabilized from highly acid ( $\mathrm{pH}<4.5)$ to slightly acid The combined $\mathrm{F}$ and $\mathrm{H}$ seepline average was 5.3 which is closer to normal for this type of wetland. The EPA region IV chronic screening values for $\mathrm{pH}$ are 6.5-9.0 (ecological) and 5.0-9.0 for human health.

The seepline south of 643-E, along a tributary of Fourmile Branch, is influenced by tritium migrating from the Burial Ground Complex. The tributary (old F-Area effluent ditch) is a natural drainage that received effluent discharge from $\mathrm{F}$-Area Separations prior to the construction of the engineered effluent canal. The March and August 1998 tritium concentrations on the east side of the natural drainage ranged from 22 to 98 and 23 to 1,320 $\mathrm{pCi} / \mathrm{ml}$ respectively. On the west-side tritium concentrations ranged from 17 to $9,840 \mathrm{pCi} / \mathrm{ml}$ and 71 to $32,300 \mathrm{pCi} / \mathrm{ml}$ respectively. The tritium activity measured in the stream of the natural drainage was $9,840 \mathrm{pCi} / \mathrm{ml}$ in March and 17,800 $\mathrm{pCi} / \mathrm{ml}$ in August. These results continue to suggest the tritium outcrop area has been delineated by the sampling locations established on the west side of the drainage channel. Conductivity and $\mathrm{pH}$ measurements taken on both sides of the drainage were similar to those recorded in September 1997, and were within the range of normal values for this wetland. The maximum tritium concentrations have declined from $59,400 \mathrm{pCi} / \mathrm{ml}$ at sample location FHB018 to a maximum of $32,300 \mathrm{pCi} / \mathrm{ml}$. The tritium concentrations during the August 1998 sampling event were much greater than have been seen in the recent past. This is illustrated in Figure 24.

\section{March and August 1998 Sampling Events Introduction}

Seepage basins in the $F$ and $H$ Areas of SRS received low-level radioactive waste effluent from the chemical separation processes in the General Separation Area, (GSA). The basins retained the effluent and allowed it to be slowly released into the soil. The waste effluent consisted principally of sodium hydroxide, nitric acid, low concentrations of various radionuclides, and some metals (Killian et al., 1985a and 1985b). Discharges of tritiated water to the seepage basins accounted for a majority of the radioactivity (Fenimore and Horton, 1972).

The Savannah River Technology Center conducted an extensive study designed to characterize the shallow groundwater outcropping into Fourmile Branch (FMB) and its associated seepline in 1988 and 1989 (Haselow et al., 1990). As a part of this study, Haselow et al. (1990) analyzed for tritium, and measured $\mathrm{pH}$, and conductivity. Researchers found low $\mathrm{pH}$ and elevated conductivity and tritium values along the seeplines and concluded that contaminants leaching from the $\mathrm{F}$ - and $\mathrm{H}$-Area Seepage Basins were impacting the wetlands below the basins. SRS discontinued discharges to the seepage basins in 1988 and sealed the basins in 1990 to isolate the contaminants from direct rainfall. Scientists hypothesized that after the elimination of the contaminant source; natural groundwater flow from annual rainfall would flush the remaining contaminant plume out of the shallow groundwater over time. After the contaminant plume in the shallow groundwater is flushed out, the impacted wetland systems immediately down gradient from the basins should recover.

To investigate this hypothesis, a quarterly sampling program was begun in May 1992 and concluded in May 1995. EAS sampled 44 of the seepline locations sampled by Haselow et al. (1990) for tritium, $\mathrm{pH}$, and specific conductivity. The 1998 
semi-annual sampling program for tritium was developed to complement the seepline sampling program for selected Appendix IX constituents, Dixon et al. (1995). The Appendix IX program began in July 1992 as a semi-annual program and since 1996 has been conducted annually. The Haselow et al. (1990) results established the baseline against which the results from the quarterly tritium sampling program are compared. These collection points were chosen as the baseline because they are the only data available that were collected before the basin discharges were discontinued. The Haselow et al. (1990) data should be representative of conditions immediately prior to closing the basins.

Later, concern was expressed about the source of tritium and other contaminants that possibly emanate from an area in the southwest corner of 643-E rather than from the closed basins. To investigate this possibility, numerous sampling locations on the H-Area seepline south of 643-E were established and were incorporated into the quarterly sampling plans beginning in March 1993.

The objectives of this report are to present the results from the March and August 1998 sampling events and trend the results from the baseline sampling events (1989 and 1992) through the latest, August 1998, sampling event.

\section{Methods}

EAS conducted the semi-annual FY98 sampling events for tritium in March and August 1998 at the same sampling locations as were selected in the quarterly tritium surveys. These locations, according to 1989 data, exhibited both high and low values for the three variables of concern (tritium, conductivity, and $\mathrm{pH}$ ). Attempts were made to establish even ground and sample coverage along each seepline.

During the March 1998 survey 58 of 63 samples were collected. During the August 1998 survey 50 of 63 samples were collected. The remaining locations from each survey were dry sites. Included in the samples collected were three stream samples taken along Fourmile Branch and one sample taken from the old F-area effluent ditch stream. Figures 1 and 3 approximate these sampling locations.

Prior to sampling for the first quarterly survey in May 1992, the Health Protection Department (HPD) collected soil samples from several locations along both seeplines and monitored them for gamma radioactivity. HPD did not detect gamma radiation above concentrations of concern; therefore, EAS selected rubber boots and disposable rubber gloves as protective clothing to prevent skin contact with seepline water during sampling operations.

Seepline sampling locations had been previously marked and labeled with PVC stakes. Samples were collected within a ten-foot radius of the PVC stake by boring a hole into the soil with a small soil auger, generally not more than eighteen inches deep. To collect water for tritium analysis, two 25 -milliliter polyethylene sample containers were filled and then capped. The outside of each container was then rinsed with deionized water, the sample container caps were wrapped with parafilm, and the containers were sealed in a small polyethylene bag to minimize the possibility of cross contamination. The small bags were then placed in a large polyethylene bag and sealed. General Engineering Laboratories (GEL) performed the tritium analysis for the standard and duplicate samples and the Environmental Monitoring Section (EMS) performed the analysis on split samples. Screening was conducted at Par Pond laboratory on all samples collected from locations with a history of containing tritium concentrations greater than $2,000 \mathrm{pCi} / \mathrm{mL}$ Chain of custody procedures were followed during the collection of all samples. A complete backup set of samples was collected for repeat analysis if required. The second $25 \mathrm{~mL}$ vial from all locations, including splits and duplicates were discarded after data validation was completed.

EAS measured specific conductivity and $\mathrm{pH}$ in situ with conductivity and $\mathrm{pH}$ electrodes (WSRC Procedure Manual L14.1, 1992a and 1992b). The electrodes were rinsed with deionized water after each measurement. All sampling equipment was thoroughly rinsed with deionized water at the end of each day. 


\section{Results and Observations}

Parameters measured at seepline sampling locations fluctuate throughout the year. Seepline measurements were taken on water collected from fixed locations at the initial point of outcropping, or toe, of the contaminant plume in the streamside wetland. Since the plume is dynamic (i.e. influenced by weather and other activities in the area) seepline monitoring is sensitive to both long term changes and seasonal/transient influences. Climatic and seasonal conditions, especially amounts of rainfall, influence measured concentrations. Groundwater flow paths in $F$ and $H$ Area are complex, as illustrated in Figures 5 and 6 . Recharge to the groundwater is primarily due to infiltration of rainwater (rainfall minus runoff and evapotranspiration). Groundwater then moves laterally, down and towards Fourmile Branch and its tributaries.

As the water travels toward Fourmile Branch, additional infiltration forces up-gradient water deeper. Near Fourmile Branch, the flow lines rise to the surface, emerging between the seepline and the stream (this acts as the groundwater "drain"). This typical vertical trajectory, a path curving downward near the groundwater divide and then upward into draining surface water, is shown as flow lines on Figures 5 and 6 .

Figure 5 shows the flow lines without contaminated water from the seepage basins and Figure 6 shows the addition of contaminated flow lines resulting from $\mathrm{F}$ and $\mathrm{H}$ Area operation of the basins. The theoretical plume geometry was confirmed by the real vertical profile of the F-Area Seepage Basin plume based on the detailed grid wells available in the 1970s (Looney et al., 1993). Changes in the water balance in the area influence the flow velocity and tend to move the plume either deeper or shallower and cause the location of the contaminated water to move. This is particularly important to data interpretation if the "toe" of the plume is shifting relative to the fixed sample locations. Figure 7 summarizes the projected changes in the plume based on a range of transitory activities. Increased rainfall (or other activities that increase infiltration such as harvesting trees) results in increased plume velocity and movement downward and away from the seepline. This decreases contaminant concentrations at the seepline sampling locations. Less infiltration decreases plume velocity and causes the plume to move upward and outcrop closer to the basins. This results in increased contaminant concentrations, as measured at the seepline sampling locations.

Low rainfall for a few months prior to sampling is expected to increase constituent concentrations, and high rainfall decreases constituent concentrations in the shallow groundwater at the seepline intercept. Rainfall measured at the SRS weather station in F Area for December 1997 through February 1998 was $57.0 \mathrm{~cm}$. The average long-term rainfall for this same period was $30.9 \mathrm{~cm}$. Thus, rainfall in the sampling area was much greater than normal for the few months prior to this sampling event. Figure 8 compares 1997/98 rainfall to the long-term average. It is hypothesized that above average rainfall observed in the area for this period would cause contaminant concentrations to decrease at sample locations closer to the basins and to increase at the more distant locations. Note that the direction of plume flow always remains the same, only the flow velocity and outcrop location changes relative to the changes in infiltration.

Rainfall measured at the SRS weather station in F Area for May 1998 through July 1998 was $30.9 \mathrm{~cm}$. The average long-term rainfall for this same period was $35.0 \mathrm{~cm}$. Thus, rainfall in the sampling area was less than normal for the few months prior to this sampling event. It is hypothesized that below average rainfall observed in the area for this period would cause contaminant concentrations to increase at sample locations closer to the basins and to decrease at the more distant locations.

During the March 1998 sampling event tritium concentrations at five sample locations were above the March 1989 readings, with these sample locations showing an average tritium activity increase of $442 \mathrm{pCi} / \mathrm{ml}$. During the August 1998 
sampling event tritium concentrations also at five sample locations were above the March 1989 readings, with these sample locations showing an average tritium activity increase of $713 \mathrm{pCi} / \mathrm{ml}$. Generally, these are the most distant sample location points from the closed basins along Fourmile Branch. Figures 9 through 14 show comparisons of March 1989 with March 1998 and August 1998 tritium, conductivity, and $\mathrm{pH}$ measurements for locations along the $\mathrm{F}$ - and $\mathrm{H}$-Area seeplines. Data for the first fifteen surveys can be found in Dixon, Rogers, and Looney (1992, 1993a, 1993b, 1993c, 1993d and 1993e and 1994), Rogers et al. (1994a, 1994b, and 1994c), Koch and Dixon (1994, 1995, 1996, and 1997), and Koch 1998. Figures 15 through 17 show the data for the Fourmile Branch stream locations. Figures 18 through 20 show the data for the sampling locations along the old effluent seepline and include one stream sample from the stream channel south of 643-E. These sampling locations were identified with the prefix FHB.

\section{F- and H-Area Seepline Tritium Measurements}

Figures 9 and 10 show tritium activities at $\mathrm{F}$ and $\mathrm{H}$ Areas for the March and August 1998 sampling events. Tritium concentrations increased by greater than $100 \mathrm{pCi} / \mathrm{mL}$ at six locations for August 1998 when compared to the previous sampling event. None of the March 1998 tritium concentrations were increased by more than $100 \mathrm{pCi} / \mathrm{ml}$ when compared to the previous sampling event. There were two dry sites during the March 1998 sampling event and twelve during the August 1998 event. The sharp contrast between tritium concentrations, when comparing March 1998 to August 1998, can generally be explained by the rainfall effects described in the previous section. Overall, sampling has shown a declining trend in tritium concentrations at the F-and H-Area seeplines (Figures 21 and 22).

It is important to note that total tritium fluxes to the wetlands and FMB have steadily declined since basin closure (Looney et al., 1993) and that overall results of these two tritium surveys support this finding. Differences in tritium concentrations measured at seepline sampling locations from one sampling event to the next represent seasonal variability and variable rainfall as well as changes due to the plume flushing from the wetland system. Variability may also result from reduction in plume size along margins.

\section{F-Area Seepline}

March 1998 tritium values in the F-Area seepline ranged from 11 to $5,160 \mathrm{pCi} / \mathrm{ml}$ (Figure 9 and Table 4). August 1998 tritium values in the F-Area seepline ranged from 6 to $8,570 \mathrm{pCi} / \mathrm{ml}$ (Figure 9 and Table 4). None of the 22 sampling locations were dry in March but six were dry in August along this seepline. One sampling location had a tritium activity exceeding the 1989 baseline measurement by more than ten percent during March and two exceeded this baseline in August. No sample exceeded the maximum value of $14,000 \mathrm{pCi} / \mathrm{ml}$ measured in March 1989 along this seepline.

As with data from previous sampling events, a Wilcoxon signed-rank test was conducted to compare March 1998 and August 1998 tritium activities to the March 1989 baseline activities and the tritium activities of each subsequent sampling event. The Wilcoxon signed-rank test uses the sign and the magnitude of the rank of the differences between pairs of measurements to compare nonparametric data (Daniel, 1978). This test was chosen because it allows comparisons of paired data without assumptions of normality. If the $P$ value is less than or equal to 0.05 , then the tritium concentrations are significantly different. The results from this test are summarized in Table $1 \mathrm{a}$ and Table $1 \mathrm{~b}$.

Figure 21 shows the downward trend of tritium concentrations and the conductivity trends in this area. It presents the mean of the tritium concentrations from each sampling event beginning with the March 1989 baseline event (Table 8). Figure 23 shows the $\mathrm{pH}$ trends using the mean $\mathrm{pH}$ value of each sampling event. 
Table 1a. Wilcoxon Signed-rank test comparing March 1998 tritium concentrations to previous sampling events:

\begin{tabular}{|c|c|c|c|}
\hline Comparison to: & P value & Comparison to: & P value \\
\hline Mar-89 & 0.002 & Jun-94 & 0.048 \\
\hline May-92 & 0.008 & Sep-94 & 0.012 \\
\hline Sep-92 & 0.009 & Dec-94 & 0.031 \\
\hline Dec-92 & 0.021 & May-95 & 0.004 \\
\hline Apr-93 & 0.299 & Mar-96 & 0.069 \\
\hline Jun-93 & 0.01 & Sep-96 & 0.004 \\
\hline Sep-93 & 0.008 & Mar-97 & 0.015 \\
\hline Dec-93 & 0.009 & Sep-97 & 0.009 \\
\hline Mar-94 & 0.06 & & \\
\hline
\end{tabular}

The results show the March tritium concentrations are significantly lower than all except the April 93 and March 96 concentrations.

Table 1b. Wilcoxon Signed-rank test comparing August 1998 tritium concentrations to previous sampling events:

\begin{tabular}{|c|c|c|c|}
\hline $\begin{array}{c}\text { Comparison } \\
\text { to: }\end{array}$ & P value & \multicolumn{2}{|c|}{ Comparison to: P value } \\
\hline Mar-89 & 0.005 & Jun-94 & 0.784 \\
May-92 & 0.841 & Sep-94 & 0.312 \\
Sep-92 & 0.189 & Dec-94 & 0.729 \\
Dec-92 & 0.546 & May-95 & 0.709 \\
Apr-93 & 0.133 & Mar-96 & 0.330 \\
Jun-93 & 0.349 & Sep-96 & 0.673 \\
Sep-93 & 0.522 & Mar-97 & 0.312 \\
Dec-93 & 0.332 & Sep-97 & 0.413 \\
Mar-94 & 0.154 & Mar-98 & 0.001 \\
\hline
\end{tabular}

The results in Table $1 \mathrm{~b}$ indicate the tritium concentrations in the August 1998 sampling event were significantly less than only the 1989 baseline results. The $P$ value of 0.001 in the March 1998 comparison indicates a significant increase rather than decrease, i.e. August 1998 tritium concentrations are significantly greater than March 1998 concentrations. The rainfall effects prior to the March and August sampling events can explain this result. There was an unusual amount of heavy rainfall prior to the March event and an unusual amount of dry weather prior to the August event.
This causes opposite effects on the movement of the toe of the plume and thus contaminant concentrations. This is a classic example of why long-term trends have to be studied when making conclusions about the significance of contaminant concentration changes.

Examining Figure 2 reveals the bulk of contaminants are outcropping between sample locations FSP040 and FSP235. Very little change in tritium concentrations occurs east of location FSP040 or west of location FSP235.

\section{H-Area Seepline}

Tritium values in the H-Area seepline for March 1998 ranged from 21 to $6,200 \mathrm{pCi} / \mathrm{ml}$ (Figure 10 and Table 5). August 1998 tritium values ranged from 8 to $6,100 \mathrm{pCi} / \mathrm{ml}$. Two of the 22 sampling locations were dry in March and six were dry in August. One sample location had tritium activities that exceeded the 1989 baseline measurements by more than ten percent in the March event and three exceeded this baseline in August. These locations, HSP071, HSP097, and HSP103 are among the farthest locations from the closed basins. No sample exceeded the maximum value of $24,000 \mathrm{pCi} / \mathrm{ml}$ measured in March 1989 at this seepline.

Figure 22 shows the downward trend of tritium concentrations and the conductivity trends in this area. It presents the mean of the tritium concentrations from each sampling event beginning with the March 1989 baseline event (Table 8). Figure 23 shows the $\mathrm{pH}$ trends using the mean $\mathrm{pH}$ value of each sampling event. 
As with data from $F$ Area, a Wilcoxon signed-rank test was conducted to compare March 1998 and August 1998 tritium activities to the March 1989 baseline activities and the activities from all previous sampling events. The result shows that the March 1998 concentrations were significantly less $(\mathrm{P}<0.05)$ than the concentrations in all fifteen previous sampling events. Table $2 \mathrm{a}$ summarizes these results.

Table 2a. Wilcoxon signed-rank test comparing March 1998 tritium concentrations to previous sampling events:

\begin{tabular}{|c|c|c|c|}
\hline Comparison to: & P value & \multicolumn{2}{|c|}{ Comparison to: P value } \\
\hline Mar-89 & $<0.001$ & Jun-94 & $<0.001$ \\
May-92 & $<0.001$ & Sep-94 & 0.003 \\
Sep-92 & $<0.001$ & Dec-94 & $<0.001$ \\
Dec-92 & $<0.001$ & May-95 & 0.008 \\
Apr-93 & $<0.001$ & Mar-96 & 0.004 \\
Jun-93 & $<0.001$ & Sep-96 & $<0.001$ \\
Sep-93 & $<0.001$ & Mar-97 & 0.008 \\
Dec-93 & $<0.001$ & Sep-97 & 0.003 \\
Mar-94 & $<0.001$ & \multicolumn{3}{|l}{} \\
\cline { 3 - 4 } & & &
\end{tabular}

The Wilcoxon Signed-rank test comparison was also made for the August 1998 sampling event. Table 2b shows the results from this comparison. The clear difference in the March and August 98 signed rank test comparisons illustrates the effects dry and wet weather can have on the significance of this comparison. The March 98 comparison in Table 2b $(p=0.013)$ indicates the August 98 tritium concentration for August was significantly greater than tritium concentrations in March 98. The tritium concentrations in August 98 were still significantly less than September 1994 and concentrations in previous event.
Table 2b. Wilcoxon signed-rank test comparing August 1998 tritium concentrations to previous sampling events:

\begin{tabular}{|c|c|c|c|}
\hline $\begin{array}{c}\text { Comparison } \\
\text { to: }\end{array}$ & P value & Comparison to: & P value \\
\hline Mar-89 & $<0.001$ & Jun-94 & 0.015 \\
May-92 & 0.004 & Sep-94 & 0.021 \\
Sep-92 & 0.015 & Dec-94 & 0.274 \\
Dec-92 & 0.015 & May-95 & 0.104 \\
Apr-93 & 0.192 & Mar-96 & 0.528 \\
Jun-93 & 0.027 & Sep-96 & 0.241 \\
Sep-93 & 0.008 & Mar-97 & 0.745 \\
Dec-93 & 0.005 & Sep-97 & 0.652 \\
Mar-94 & 0.073 & Mar-98 & $0.013^{*}$ \\
\hline
\end{tabular}

Sampling locations closest to the closed basins show a distinctly decreasing trend. The locations furthest from the closed basins show a definite increasing trend. This supports the hypothesis that the contaminants are flushing from the system.

\section{F- and H-Area Seepline Conductivity Measurements}

\section{F-Area Seepline}

Conductivity measurements at the F-Area seepline in March 1998 ranged from 11 to $5,160 \mu \mathrm{S} / \mathrm{cm}$ and 10 to $8,570 \mu \mathrm{S} / \mathrm{cm}$ for August 1998 (Figure 11, Table 4). Due to the variability of conductivity measurements, only differences of $100 \mu \mathrm{S} / \mathrm{cm}$ or more are considered significant. Of the 22 locations sampled in March 1998, one location measured more than $100 \mu \mathrm{S} / \mathrm{cm}$ above the 1989 baseline measurements. Three of the twenty sample locations taken in August 1998 measured more than 100 $\mu \mathrm{S} / \mathrm{cm}$ above the 1989 baseline measurements. A comparison of the results in Figures 9 and 11 suggests that conductivity follows the same general trends as the tritium activities. 
Using a Spearman rank correlation test for nonparametric data, the probability that tritium and conductivity exhibited independent trends was low, $(\mathrm{P}<0.001)$. The Spearman rank correlation coefficients were calculated to be $r_{S}=0.86$ and 0.78 for the March and August 1998 sampling events respectively. This suggests that the two parameters behave dependently for both events. This similarity of trends between conductivity and tritium is consistent with past results. In past tritium surveys, 1992 through March 1997, this correlation has been positive and significant. A rank correlation coefficient of 1.0 is a perfect correlation between variables.

\section{H-Area Seepline}

Conductivity measurements in March and August 1998 at the H-Area seepline ranged from 26 to 316 $\mu \mathrm{S} / \mathrm{cm}$ and 29 to $308 \mu \mathrm{S} / \mathrm{cm}$ respectively (Figure 12 and Table 5). No sampling location had a measurement of more than $100 \mu \mathrm{S} / \mathrm{cm}$ above the 1989 baseline measurements in March 1998 and only one did in August 1998. The Spearman rank correlation test was used to investigate the correlation of tritium activities and conductivity values. The probability that the two parameters exhibited independent trends was low on this seepline for both the March and August 1998 event $(\mathrm{P}<0.001$ for each event). The rank correlation coefficient $\left(r_{s}=0.65\right.$ and 0.73$)$ was less than for $F$ Area seepline locations suggesting a weaker correlation but still dependent behavior between variables. Past surveys have shown this correlation to be positive and significant.

\section{F- and H-Area Seepline pH Measurements}

The $\mathrm{pH}$ values during March and August 1998 in the F-Area seepline ranged from 4.0 to 5.9 , and 3.7 to 6.2 respectively with an average values of 4.8 and 4.9 (Figure 13, Table 4). H- Area $\mathrm{pH}$ values ranged from 4.7 to 6.5 during the March event and 4.5 to 6.3 in the August 1998 event, with averages of 5.8 and 5.7 respectively (Figure 14 and Table 5). The $\mathrm{pH}$ for the entire seepline ( $\mathrm{F}$ and $\mathrm{H}$ Areas combined) averaged 5.3 in March and 5.2 in August 1998. The overall average for 1989 was 4.9. An increase in $\mathrm{pH}$ will effect the solubility of metals in the soil, which should improve the soil water chemistry and enhance the recovery of wetland vegetation stressed indirectly by low $\mathrm{pH}$.

Aluminum concentrations measured along the seepline in 1989 were high enough to be toxic to plants (Haselow et al., 1990). Increases in $\mathrm{pH}$ from an average of 4.9 (in 1989) have likely reduced the amount of aluminum in solution and thereby reduced it as a possible source of plant toxicity. Concentrations of aluminum and other metals measured along the seepline in March 1997 were substantially lower than 1989 concentrations, consistent with the observed $\mathrm{pH}$ (Koch and Dixon, 1998). Field observations have revealed that vegetation in most of the stressed areas is making noticeable recovery (Nelson and Irwin, 1994; Nelson and Rogers, 1995). Studies have also shown that the toxicity of these areas is decreasing, (Nelson and Westbury, 1994; Westbury and Nelson, 1994).

\section{Fourmile Branch Measurements}

Figures 15 through 17 show the tritium, conductivity, and $\mathrm{pH}$ values for the Fourmile Branch stream sampling locations. Table 6 provides the data used in the figures. Tritium activities at these locations ranged from 4 to $39 \mathrm{pCi} / \mathrm{ml}$ during the March 1998 survey and 25 to $256 \mathrm{pCi} / \mathrm{ml}$ during the August 1998 survey. These values consistently show that tritium concentrations increase as samples are collected further downstream along this stream (as the seepline water enters the channel of Fourmile Branch). In the March 1998 survey conductivity measurements ranged from 22 to $34 \mu \mathrm{S} / \mathrm{cm}$ and $\mathrm{pH}$ ranged from 5.6 to 5.9. During the August survey conductivity measurements ranged from 53 to 91 $\mu \mathrm{S} / \mathrm{cm}$ and $\mathrm{pH}$ ranged from 5.7 to 6.3 . 


\section{Solid Waste Disposal Facility (643-E) Seepline Measurements}

The graphs in Figures 18 through 20 show tritium, conductivity, and $\mathrm{pH}$ values for the seepline and stream sampling locations south of 643-E, which is part of the Solid Waste Disposal Facility. Table 7 provides the data used in the figures. This seepline is along the natural drainage (old F-Area effluent ditch) that was used to discharge effluent from FArea separations prior to the construction of the engineered effluent canal.

Tritium activities ranged from 17 to 9,840 and 23 to $32,300 \mathrm{pCi} / \mathrm{ml}$ during the March and August 1998 survey respectively. The tritium activity at the stream location in the drainage (FHB012) was 21,300 and $17,800 \mathrm{pCi} / \mathrm{ml}$ for the two respective surveys.

In March 1998, $\mathrm{pH}$ values ranged from 4.7 to 5.8, with an average of 5.0 . The August $1998 \mathrm{pH}$ range was 4.5 to 5.8 with an average of 5.0.

Conductivity measurements on both sides of the drainage were near background at most locations and ranged from 29 to $276 \mu \mathrm{S} / \mathrm{cm}$ in March and 11 to $106 \mu \mathrm{S} / \mathrm{cm}$ in August 1998. Conductivity values were typical of the conductivity values being reported in the water table wells in the vicinity of the old F-Area effluent ditch (EMS, 1996). The Spearman rank correlation test was conducted to determine if any relationship existed between tritium and conductivity. For both the March and August 1998 survey this rank coefficient was small $(0.022$ and 0.185$)$ respectively and indicated a high probability that these two variables were behaving independently. Past Spearman rank correlation test results showed no correlation between conductivity and tritium.

The tritium results were consistent with the Haselow et al. (1990) results for the west side sample locations of the 643-E seepline, particularly near location HSP103. Haselow et al. (1990) found that down gradient from $643-\mathrm{E}$, conductivity values were near background whereas tritium concentrations were elevated. This finding was attributed to tritiated wastes deposited in 643-E. Tritium activities measured along the seepline down gradient of 643-E (particularly sample points on the west side of the drainage) suggest that tritium migrating from 643-E and outcropping in this area was substantial. The detection of tritium on the west side (as opposed to the east side of the drainage) suggested that soil material placed in the northern reaches of the natural drainage forced the tritium plume to outcrop down gradient. It appears that the groundwater containing tritium is moving below the fill material and outcropping on the west side of the drainage channel. The results suggest that the sampling locations on the west side of the drainage have delineated the tritium plume with the center located at or near FHB018.

Figure 24 shows the tritium data from all the sampling events for this seepline area beginning with the 1992 sampling event. The higher tritium activity locations occur at four locations, all on the west side of the drainage. These locations are FHB013, 017, 018, and 019.

\section{Overall Trends, and Summary 1989 Through 1998}

\section{F-Area Seepline}

Figure 21 shows the downward trend of tritium concentrations for the F-Area seepline and the conductivity trends. It shows the mean tritium and conductivity concentrations from each sampling event beginning with the March 1989 baseline event through the March 1998 sampling event (Table 8). Each sampling event since 1989 has shown a statistically significant decrease in tritium concentrations when compared to the 1989 baseline event. Figure 23 shows the $\mathrm{pH}$ trends using the mean $\mathrm{pH}$ of each sampling event. 
Figure 21 shows the tritium concentrations for all the sampling events at the F-Area seepline. It indicates that a majority of the tritium measured appears at eight of the 22 sample locations. These locations, are FSP019, 026, 032, 034, 035, 040, 204, and 213 . Very little of the tritium plume has been detected east of sample location FSP040 or south and west of sample location FSP0213. It also appears that two distinct groupings of sample locations delineate the bulk of the tritium plume from the seepage basins. Road C-4 separates these two groupings.

Table 11 shows the sample collection summary for the F-Area seepline from 1989-1997.

\section{$\underline{\text { H-Area Seepline }}$}

Figure 22 shows the downward trend of tritium concentrations for the $\mathrm{H}$-Area seepline and the conductivity trends. This figure shows the mean tritium and conductivity concentration from each sampling event beginning with the March 1989 baseline event through the August 1998 sampling event (Table 8). Figure 23 shows the $\mathrm{pH}$ trends using the mean $\mathrm{pH}$ of each sampling event. Each sampling event since 1989 has shown a statistically significant decrease in tritium concentrations when compared to the 1989 baseline event.

Figure 4 shows the tritium concentrations from all the sampling events conducted for the H-Area seepline. The sample locations having the highest and lowest tritium values over the entire sampling interval (1989 to 1998) can be seen from examining this figure.

Table 12 shows a sample collection summary for the H-Area seepline from 1989 through 1998.

\section{$\underline{643-E}$}

Figures 24 shows the mean tritium concentration of each sampling event. The delineation of the contamination between the east and west side drainage is also shown in this figure.
Table 13 shows a sample collection summary for the 643-E seepline area from 1992 through 1998

\section{Fourmile Branch}

Figures 27 to 29 show the tritium concentrations, conductivity, and $\mathrm{pH}$ measurements for the Fourmile Branch sample locations from 1992 to 1998. Each point represents the actual concentration or reading and is not an average value.

\section{Conclusions}

The difference in tritium concentrations between sampling events can be attributed to rainfall and seasonal variability, as well as changes from the contaminant plume flushing from the wetland system. Conclusions about tritium fluxes into the wetlands and FMB should consider the complexity of the groundwater system. They should also be based on long-term surface water, seepline, and groundwater monitoring data and not on quarterly changes in concentrations at seepline monitoring locations. No correction has been made for tritium decay.

\section{F-and H-Area Seeplines, and Fourmile Branch}

- Tritium concentrations measured along the FArea seepline during March 1998 were significantly lower than fifteen of the previous seventeen event concentrations.

- Tritium concentrations measured along the FArea seepline during August 1998 were significantly lower than only the 1989 baseline event concentrations.

- Tritium concentrations measured along the HArea Seepline during March 1998 were significantly lower than all previous sampling event concentrations including the previous event (September 1997) concentrations.

- Tritium concentrations measured along the $\mathrm{H}$ Area Seepline during August 1998 were significantly lower than ten of the previous surveys (March 1989 through September 1994. 
- Total tritium fluxes to the wetlands and FMB have steadily declined since basin closure (Looney et al., 1993). Overall results from the two 1998 tritium surveys support this finding. These findings continue to support the hypothesis that the tritium plume in $\mathrm{F}$ and $\mathrm{H}$ Area is being flushed from the shallow groundwater.

- A majority of the tritium detected along the FArea seepline appeared at two localized areas (i.e., eight of the 22 sample locations). These eight sample locations are FSP019, 026, 032, 034, 035, 040, 204 and 213.

\section{Solid Waste Disposal Facility (643-E) Seepline}

Data from 16 seepline locations south of the 643-E Area indicated that tritium migrating from $643-\mathrm{E}$ is outcropping at the F- Area effluent ditch, particularly on the west side of the stream channel. It appears that sampling locations on the west side of the ditch have delineated the tritium outcrop area with the present climatic and hydrologic conditions.

One tritium result from the two 1998 surveys was above $20,000 \mathrm{pCi} / \mathrm{ml}$. It was located on the west side of the seepline. A major portion of the tritium detected was on the west side of the drainage at four sample locations. These four sample locations were FHB013, 017,018 , and 019 .

\section{References}

Daniel, W.W. 1978. Applied Nonparametric Statistics. Houghton Mifflin Company, Boston, MA.

Dixon, K.L. and V.A. Rogers. 1992a. Results of the First Quarter Tritium Survey of the F- and $\mathrm{H}$ Area Seeplines: May 1992. WSRC-TR-92-304, Westinghouse Savannah River Company, Savannah River Technology Center, Aiken, SC

Dixon, K.L. and V.A. Rogers. 1993b. Results of the Second Quarter Tritium Survey of the F- and H-
Area Seeplines: September 1992. WSRC-TR93-129, Westinghouse Savannah River Company, Savannah River Technology Center, Aiken, SC.

Dixon, K.L. and V.A. Rogers. 1993c. Results of the Third Quarter Tritium Survey of the F- and HArea Seeplines: December 1992. WSRC-TR-93284, Westinghouse Savannah River Company, Savannah River Technology Center, Aiken, SC.

Dixon, K.L. and V.A. Rogers. 1993d. Results of the Fourth Quarter Tritium Survey of the F- and HArea Seeplines: April 1993. WSRC-TR-93526, Westinghouse Savannah River Company, Savannah River Technology Center, Aiken, SC.

Dixon, K.L. and V.A. Rogers. 1993e. Results of the Quarterly Tritium Survey of Fourmile Branch and its Seeplines in the F- and H-Areas of SRS: June 1993. WSRC-TR-93-656, Westinghouse Savannah River Company, Savannah River Technology Center, Aiken, SC.

Dixon, K.L., and V.A. Rogers, and B.B. Looney. 1994. Results of the Quarterly Tritium Survey of Fourmile Branch and its Seeplines in the F and $H$ Areas of SRS: September 1993 (U) WSRC-TR-94-0286-ESS, Westinghouse Savannah River Company, Savannah River Technology Center, Aiken, SC.

Dixon, K.L., J.W. Koch, and V.A. Rogers. 1995. Semi-Annual Sampling of Fourmile Branch and Its Seeplines in the $\mathrm{F}$ and $\mathrm{H}$ Areas of SRS: February 1993, July 1993, and April 1994. (U) WSRC-TR-95-0454, Rev. 1, Westinghouse Savannah River Company, Savannah River Technology Center, Aiken, SC.

Environmental Monitoring Section. 1993. The Savannah River Site's Ground Water Monitoring Program, Second Quarter Report. ESH-EMS-930097, Westinghouse Savannah River Company, Aiken SC. 
Fenimore, J.W. and J.H. Horton. 1972. Rating History and Environmental Effects of Seepage

Basins in Chemical Separations Areas of the Savannah River Plant. DPST-72-548, E.I. du Pont de Nemours and Company, Savannah River Laboratory, Aiken, SC.

Haselow, J.S., M. K. Harris, B.B. Looney, N.V. Halverson, and J.B. Gladden. 1990. Analysis of Soil and Water at the Fourmile Branch Seepline Near the F and H Area of SRS (U). WSRC-RP90-0591, WSRC-TR-92-304, Westinghouse Savannah River Company, Savannah River Technology Center, Aiken, SC. Savannah River Laboratory, Aiken, SC.

Killian, T.H., N.L. Kolb, P. Corbo, and I.W. Marine. 1985a. F-Area Seepage Basins. DPST-85-704, E.I. du Pont de Nemours and Company, Savannah River Laboratory, Aiken, SC.

Killian, T.H., N.L. Kolb, P. Corbo, and I.W. Marine. 1985b. H-Area Seepage Basins. DPST-85-706, E.I. du Pont de Nemours and Company, Savannah River Laboratory, Aiken, SC.

Koch, J.W. and K.L. Dixon. 1994. Results of the Quarterly Tritium Survey of Fourmile Branch and its Seeplines in the F and H Areas of SRS: December 1994. (U) WSRC-TR-95-0300, Westinghouse Savannah River Company, Savannah River Technology Center, Aiken, SC.

Koch, J.W. and K.L. Dixon. 1995. Results of the Quarterly Tritium Survey of Fourmile Branch and its Seeplines in the F and H Areas of SRS: May 1995. (U) WSRC-TR-95-0369, Westinghouse Savannah River Company, Savannah River Technology Center, Aiken, SC.

Koch, J.W. and K.L. Dixon. 1996. Results of the Tritium Survey of Fourmile Branch and its Seeplines in the F and H Areas of SRS: March 1996 WSRC-TR-96-0215, Westinghouse Savannah River Company, Savannah River Technology Center, Aiken, SC.
Koch, J.W. and K.L. Dixon. 1997. Results of the Tritium Survey of Fourmile Branch and its Seeplines in the F- and H-Areas of SRS: September 1996 and 1989-1996 Trending (U) WSRC-TR-97-0109, Westinghouse Savannah River Company, Savannah River Technology Center, Aiken, SC.

Koch, J.W. and K.L. Dixon. 1997. Tritium Concentrations in the F- and H-Area Seeplines and Fourmile Branch at SRS: March 1997 and 1989-1997 Trending (U). WSRC-TR-97-0359, Westinghouse Savannah River Company, Savannah River Technology Center, Aiken, SC.

Koch, J.W. and K.L. Dixon. 1998. Comprehensive Sampling of Fourmile Branch and Its Seeplines in the F and H Areas of SRS: June 1996, and March 1997 (U) WSRC-TR-98-00287, Westinghouse Savannah River Company, Savannah River Technology Center, Aiken, SC.

Koch, J.W. and K.L. Dixon. 1997. Tritium Concentrations in the F- and H-Area Seeplines and Fourmile Branch at SRS: September 1997 and 1989-1997 Trending (U). WSRC-TR-9800365, Westinghouse Savannah River Company, Savannah River Technology Center, Aiken, SC.

Looney, B.B., J.S. Haselow, C.M. Lewis, M.K. Harris, D.E. Wyatt, C.S. Hetrick. 1993. Projected Tritium Releases from F \& H Area Seepage Basins and the Solid Waste Disposal Facilities to Fourmile Branch (U). WSRC-RP93-459, Westinghouse Savannah River Company, Savannah River Technology Center, Aiken, SC.

Nelson, E.A. and , J.E. Irwin 1994. Current Vegetation Characteristics within Tree-Kill Zones of $\mathrm{F}$ and $\mathrm{H}$ Areas (U) WSRC-TR-940203 Westinghouse Savannah River Company, Savannah River Technology Center, Aiken, SC. 
Nelson, E. A. and H.M. Westbury, Jr. 1994 Lettuce Seed Germination and Root Elongation Toxicity

Evaluation of the F-Area Seepline Soils (U) WSRCTR-94-0510 Westinghouse Savannah River Company, Savannah River Technology Center, Aiken, SC.

Nelson, E.A. and V.A. Rogers, 1995. Survival of Planted Tupelo Seedlings in F- and H-Area Tree-Kill Zones (U) WSRC-TR-95-0025 Westinghouse Savannah River Company, Savannah River Technology Center, Aiken, SC.

Rogers, V.A., K.L. Dixon, and B.B. Looney. 1994a. Results of the Quarterly Tritium Survey of Fourmile Branch and its Seeplines in the F and H Areas of SRS: December 1993. (U) WSRCTR-94-0342, Westinghouse Savannah River Company, Savannah River Technology Center, Aiken, SC.

Rogers, V.A., K.L. Dixon, and B.B. Looney. 1994b. Results of the Quarterly Tritium Survey of Fourmile Branch and its Seeplines in the F and H Areas of SRS: March 1994. (U) WSRC-TR94-0408, Westinghouse Savannah River Company, Savannah River Technology Center, Aiken, SC.

Rogers, V.A., K.L. Dixon, and B.B. Looney. 1994c. Results of the Quarterly Tritium Survey of Fourmile Branch and its Seeplines in the F and H Areas of SRS: June 1994. (U) WSRC-TR-940441, Westinghouse Savannah River Company, Savannah River Technology Center, Aiken, SC.

Westbury, H.M. Jr. and E.A. Nelson, 1994. Plant Community Development Within the F- and $\mathrm{H}$ Area Tree-Kill Zones (U) WSRC-TR-94-0544 Westinghouse Savannah River Company, Savannah River Technology Center, Aiken, SC. 


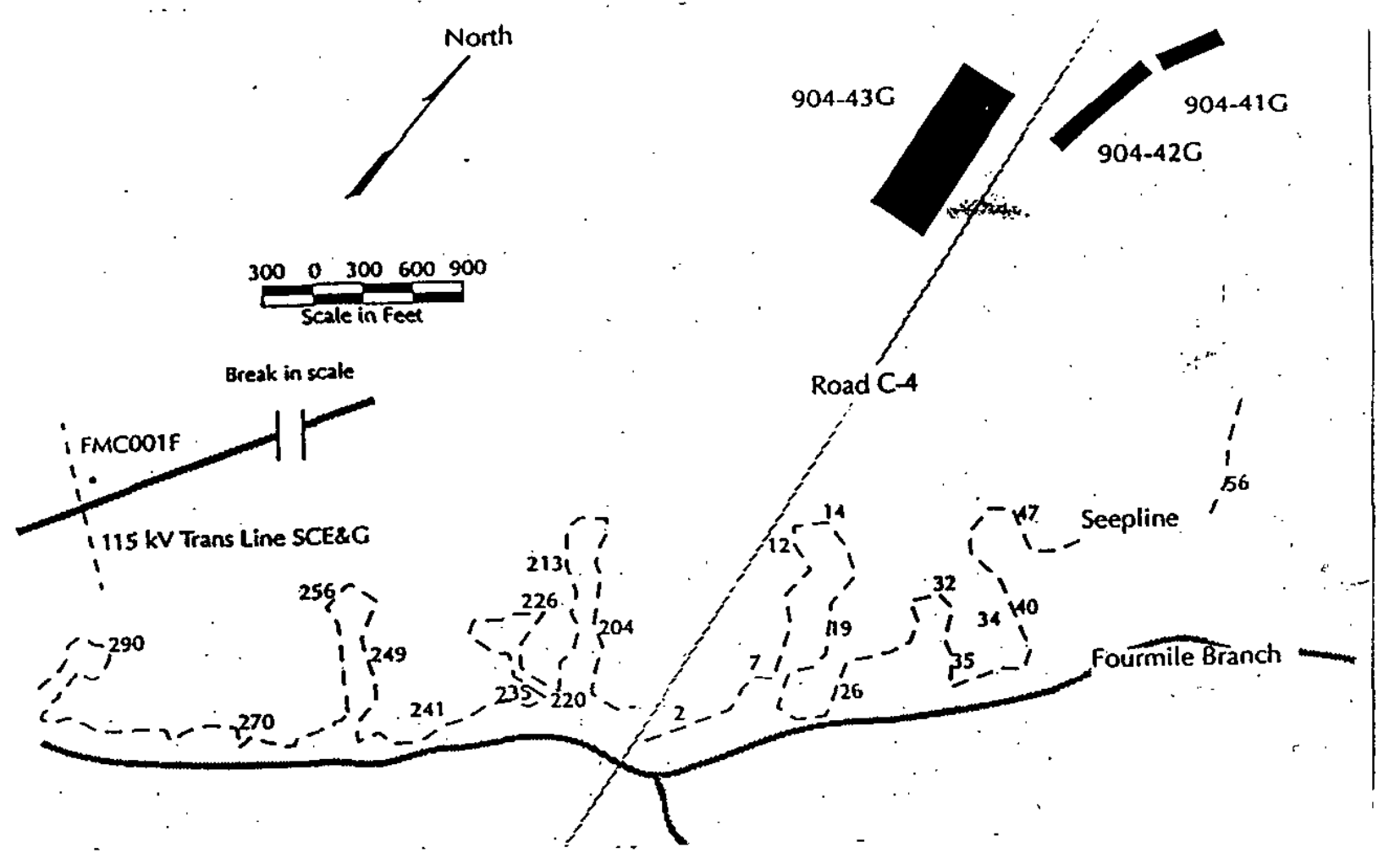

Figure 1. Location of F-Area Seepage Basins and Seepline Sampling Points.

\section{Tritium Concentration $(\mathrm{pCi} / \mathrm{ml})$}

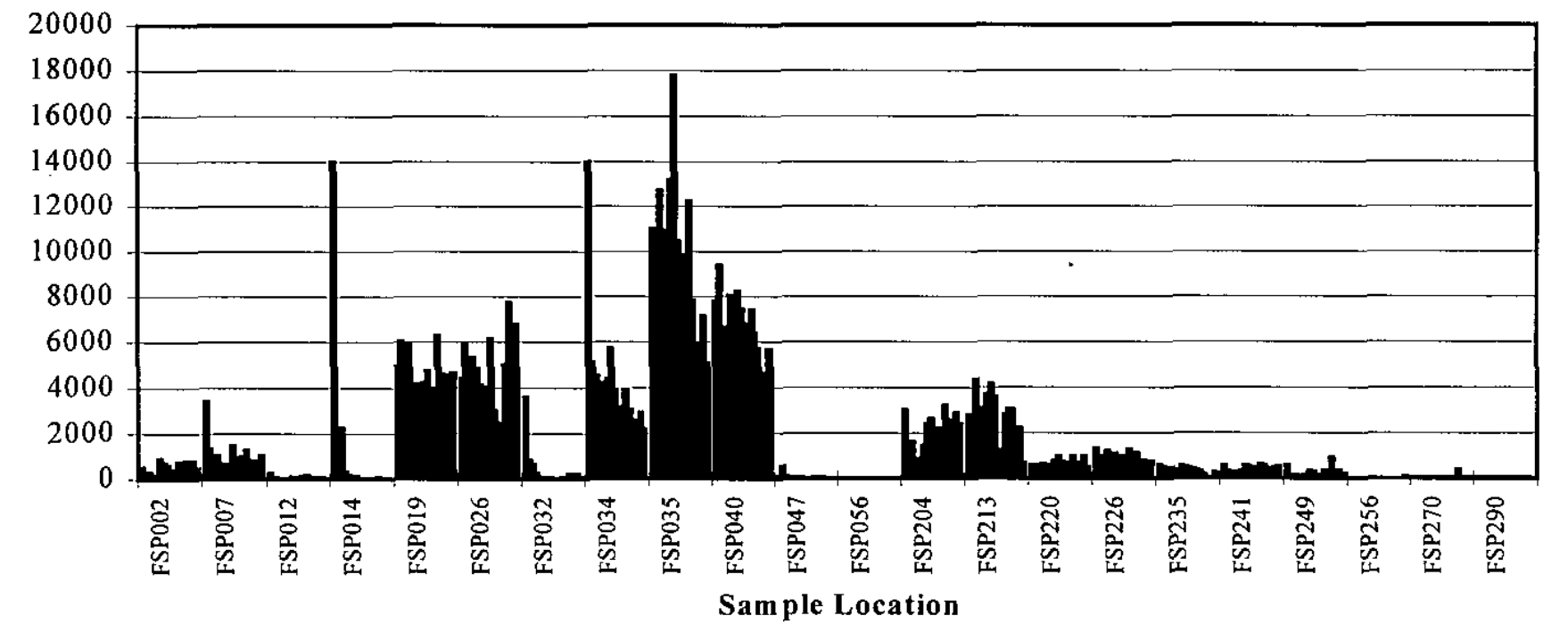

Figure 2. Tritium concentrations for F-Area Seepline (1989-1998). This plot shows the distribution of tritium throughout the entire sampling period. 
Results of the Tritium Survey in the F and $H$ Area Seepline and Fourmile Branch at SRS: March 1998 and August 1998 Sampling Events and 1989-1998 Summary

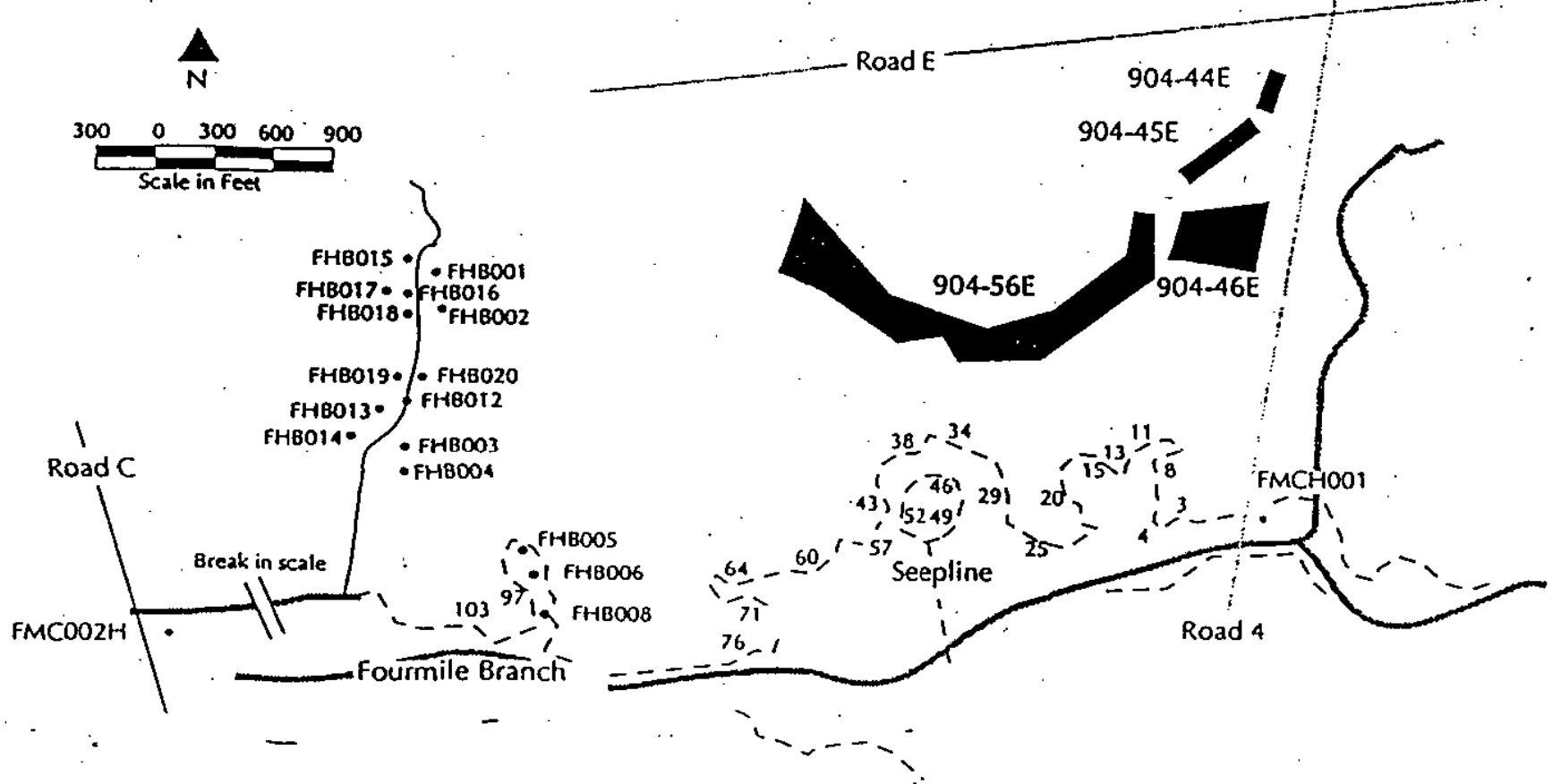

Figures 3. Location of $\mathrm{H}$-Area Seepage Basins and Seepline Sampling Points and FHB Sampling Points.

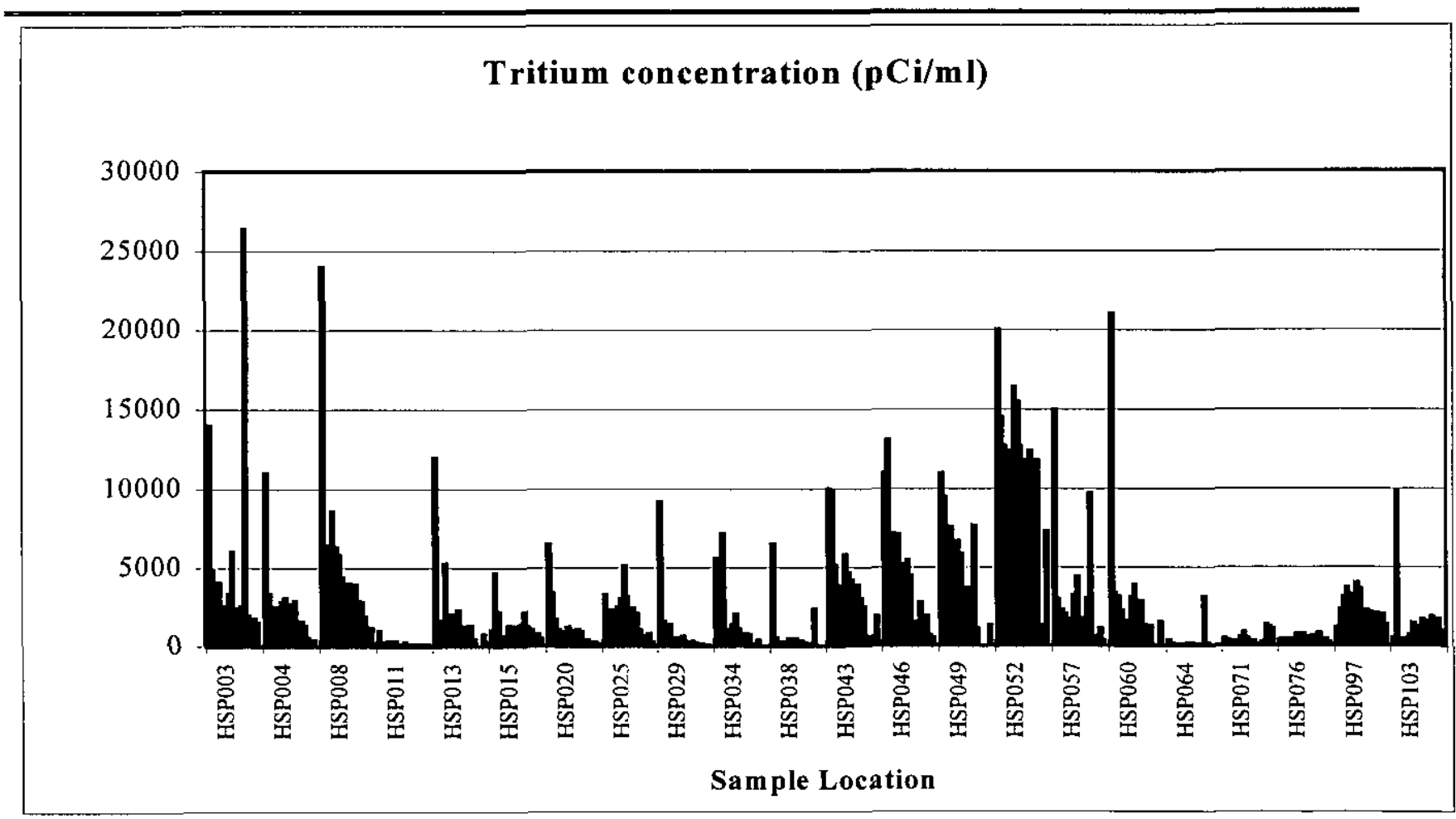

Figure 4. Tritium concentrations at the H-Area Seepline (1989-1998). This plot shows the distribution of tritium throughout the entire sampling period. 

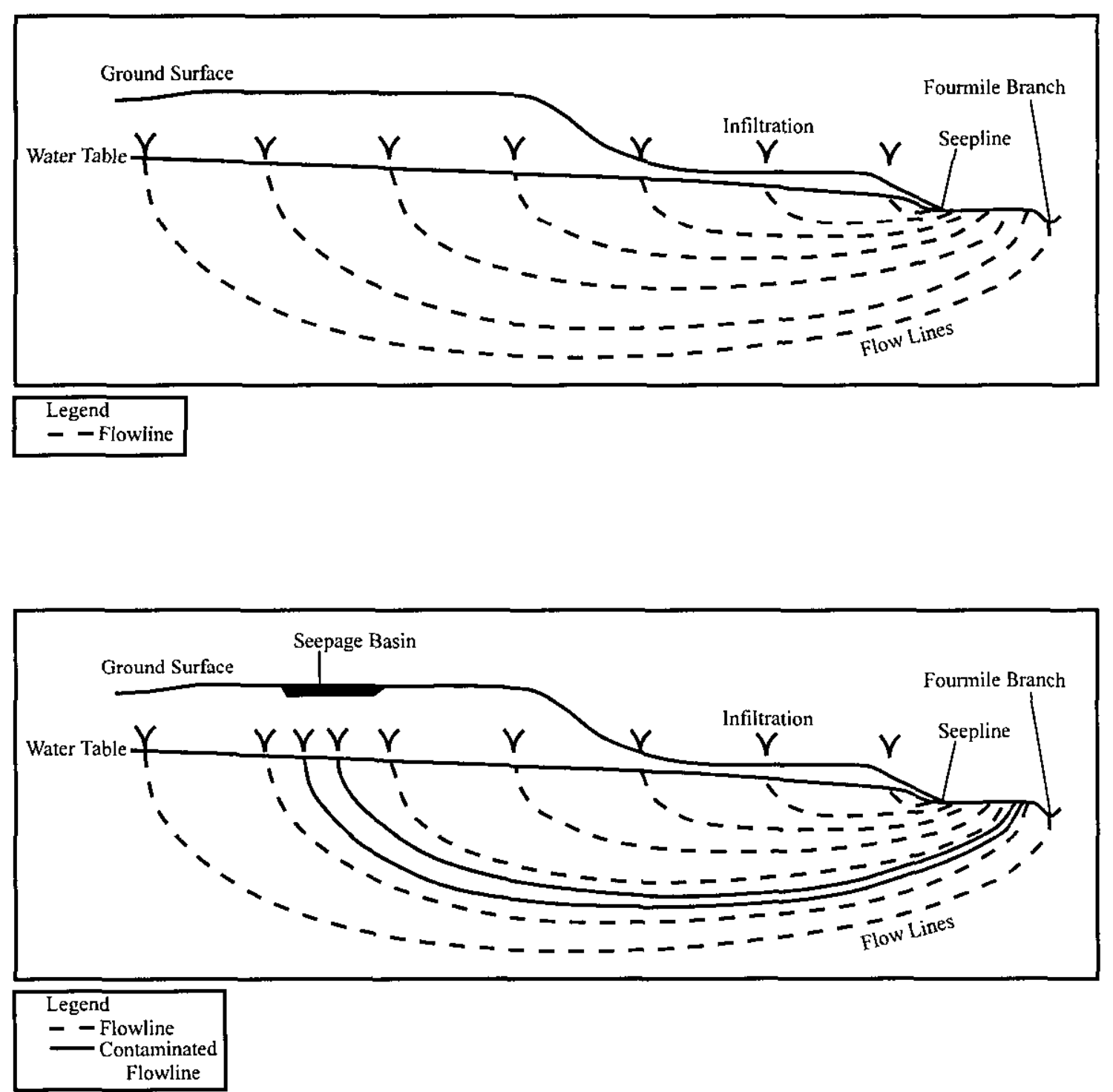

Figures 5 and 6. Schematic diagram of flow lines before and after closure of seepage basins. 
Results of the Tritium Survey in the $F$ and $H$ Area Seepline and Fourmile Branch at SRS: March 1998 and August 1998 Sampling Events and 1989-1998 Summary

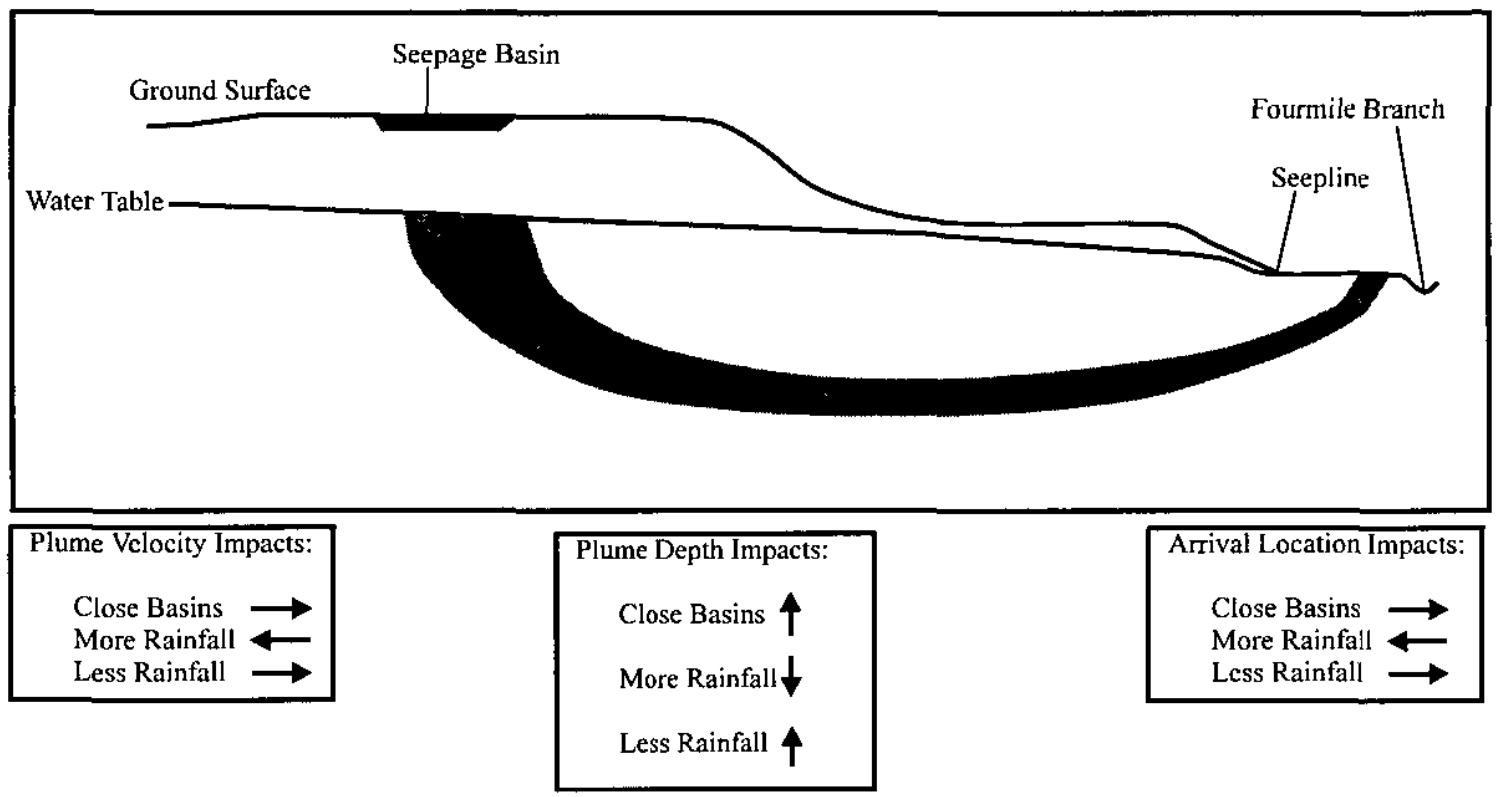

Figure 7. Schematic Diagram of the Tritium Plume Migrating from F- and H-Area Seepage Basins and rainfall effects

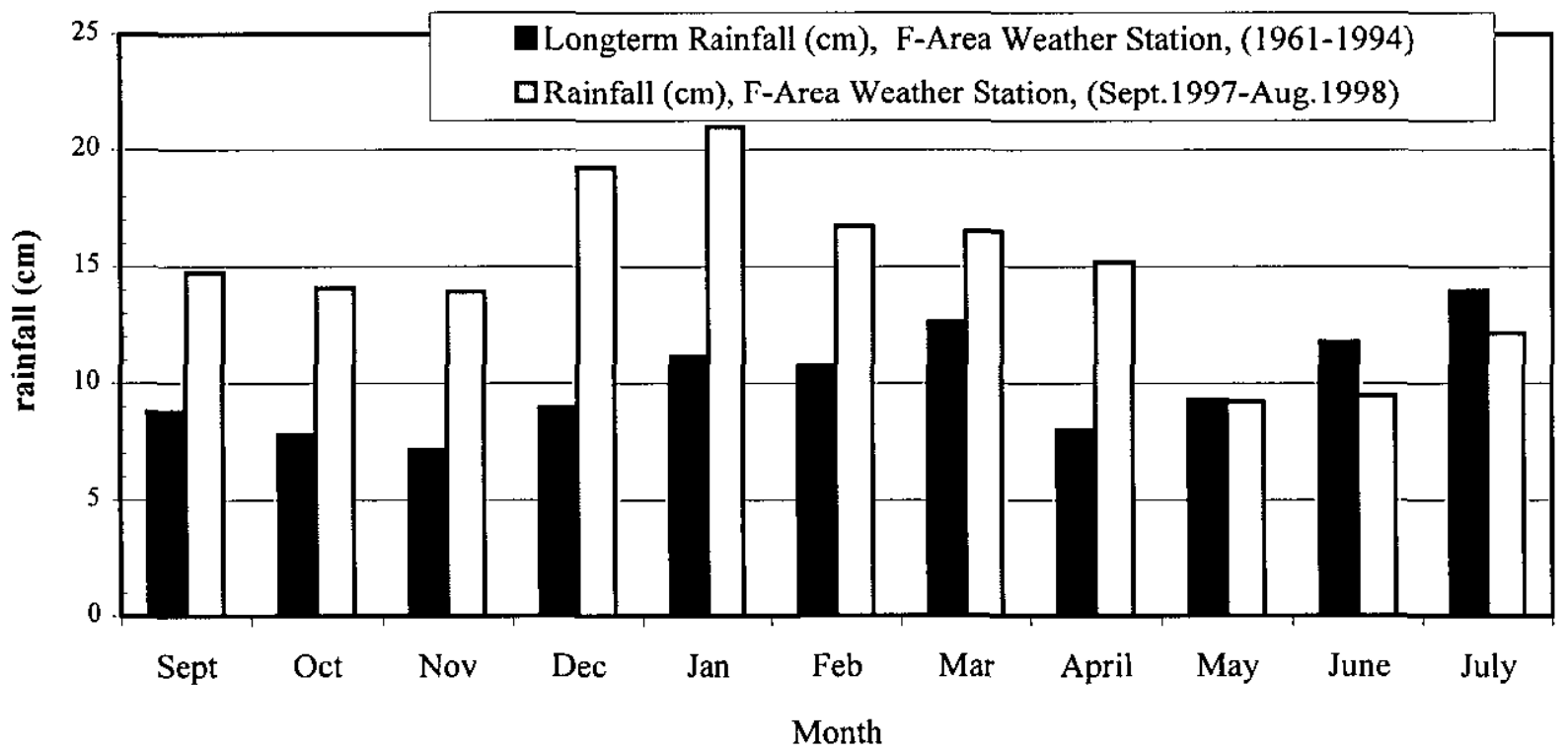

Figure 8. Comparison of September 1997 through August 1998 Monthly Rainfall to the Long Term Average (1961-1994) for the F-Area Weather Station. 


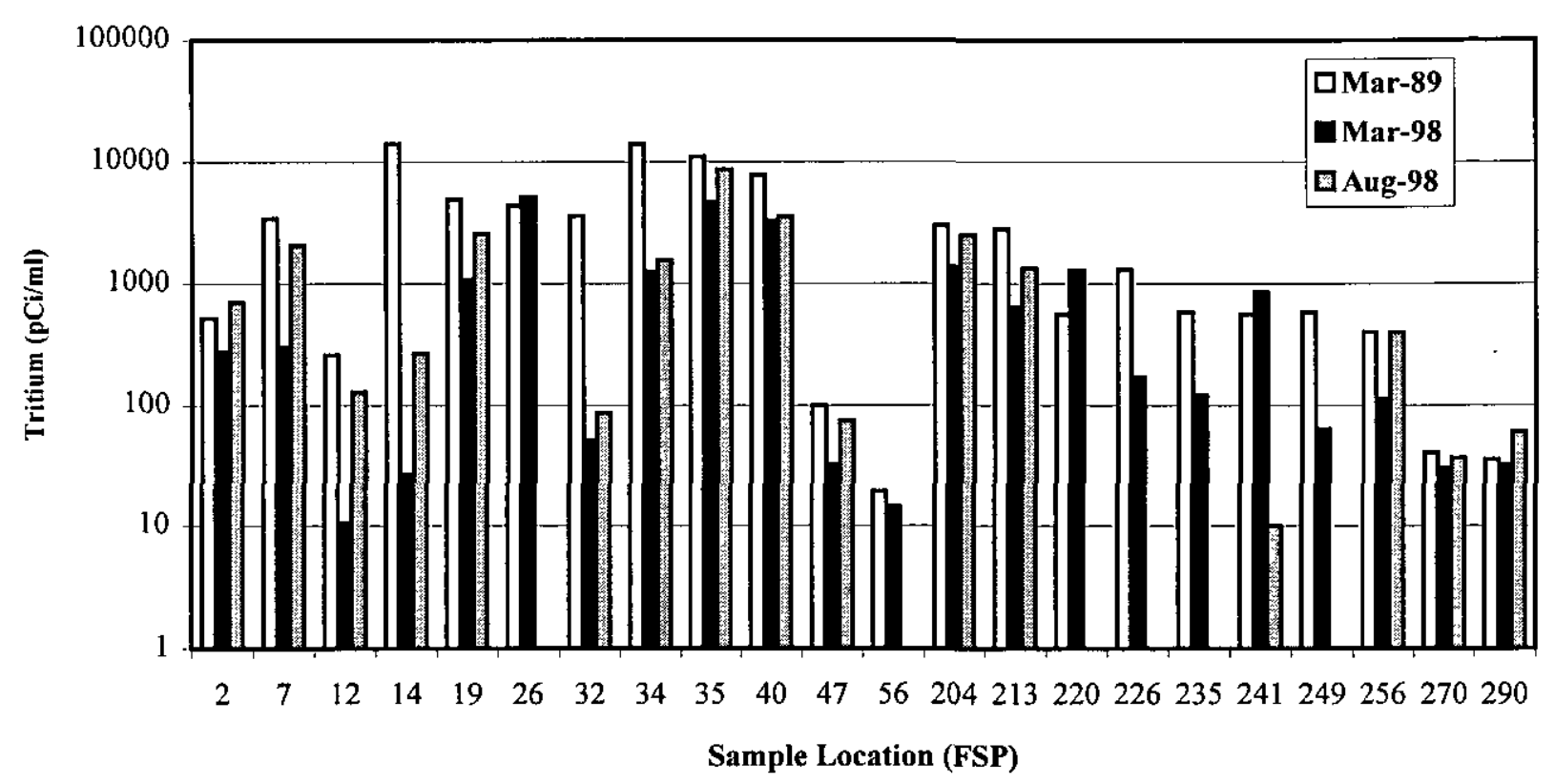

Figure 9. Comparison of Tritium Concentration at F-Area Seepline Locations

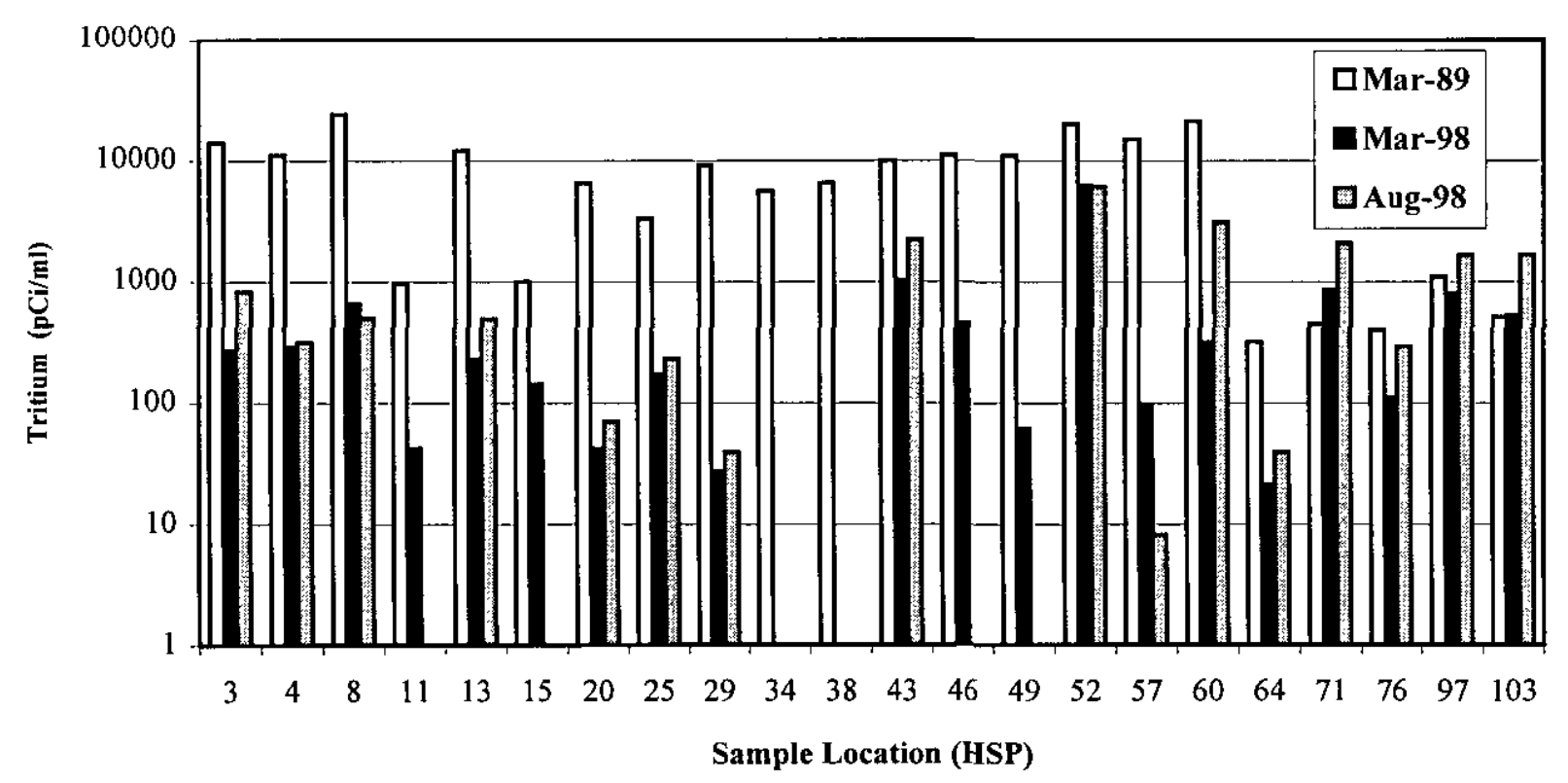

Figure 10. Comparison of Tritium Concentration at H-Area Seepline Locations 


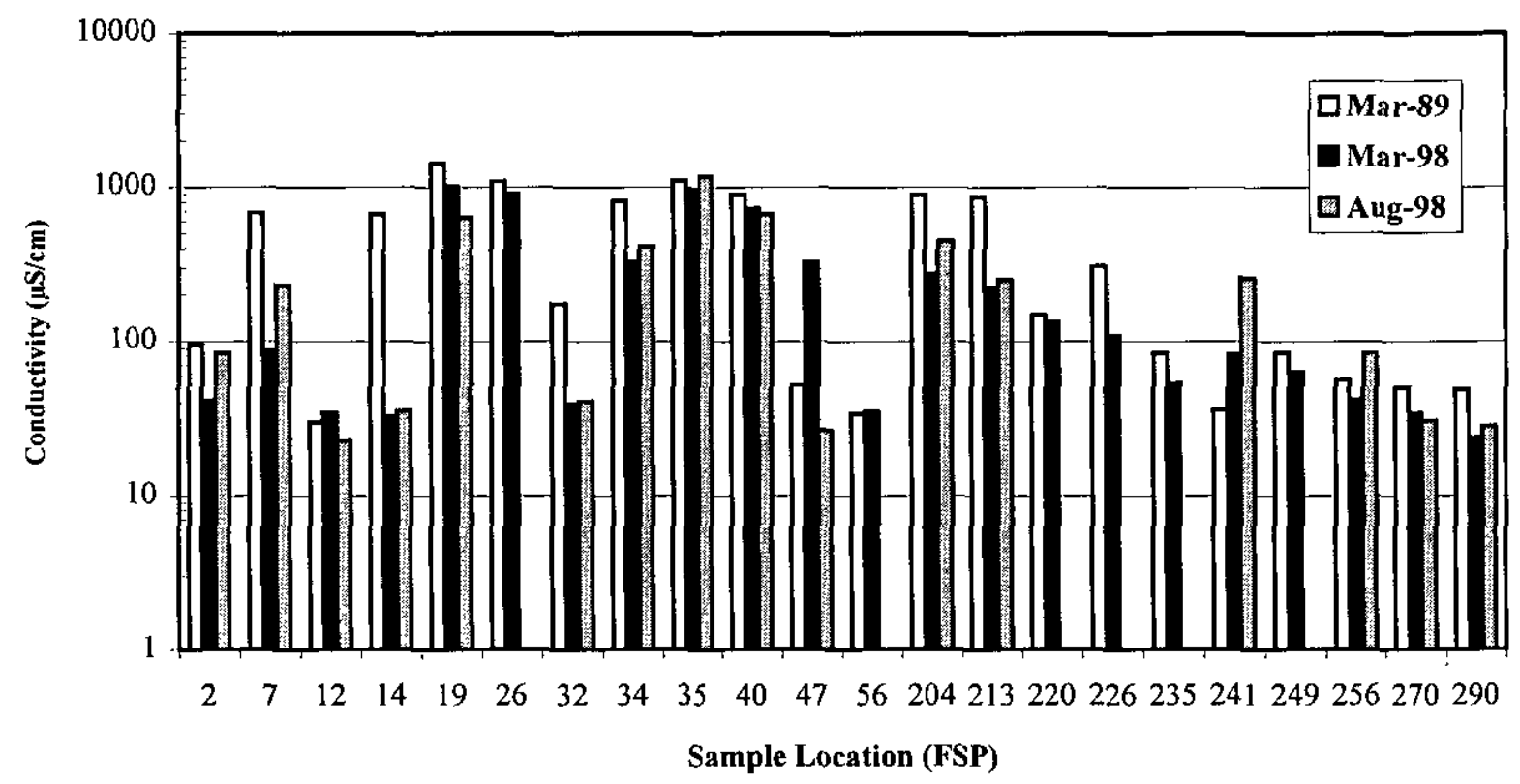

Figure 11. Comparison of Specific Electrical Conductivity at F-Area Seepline Locations

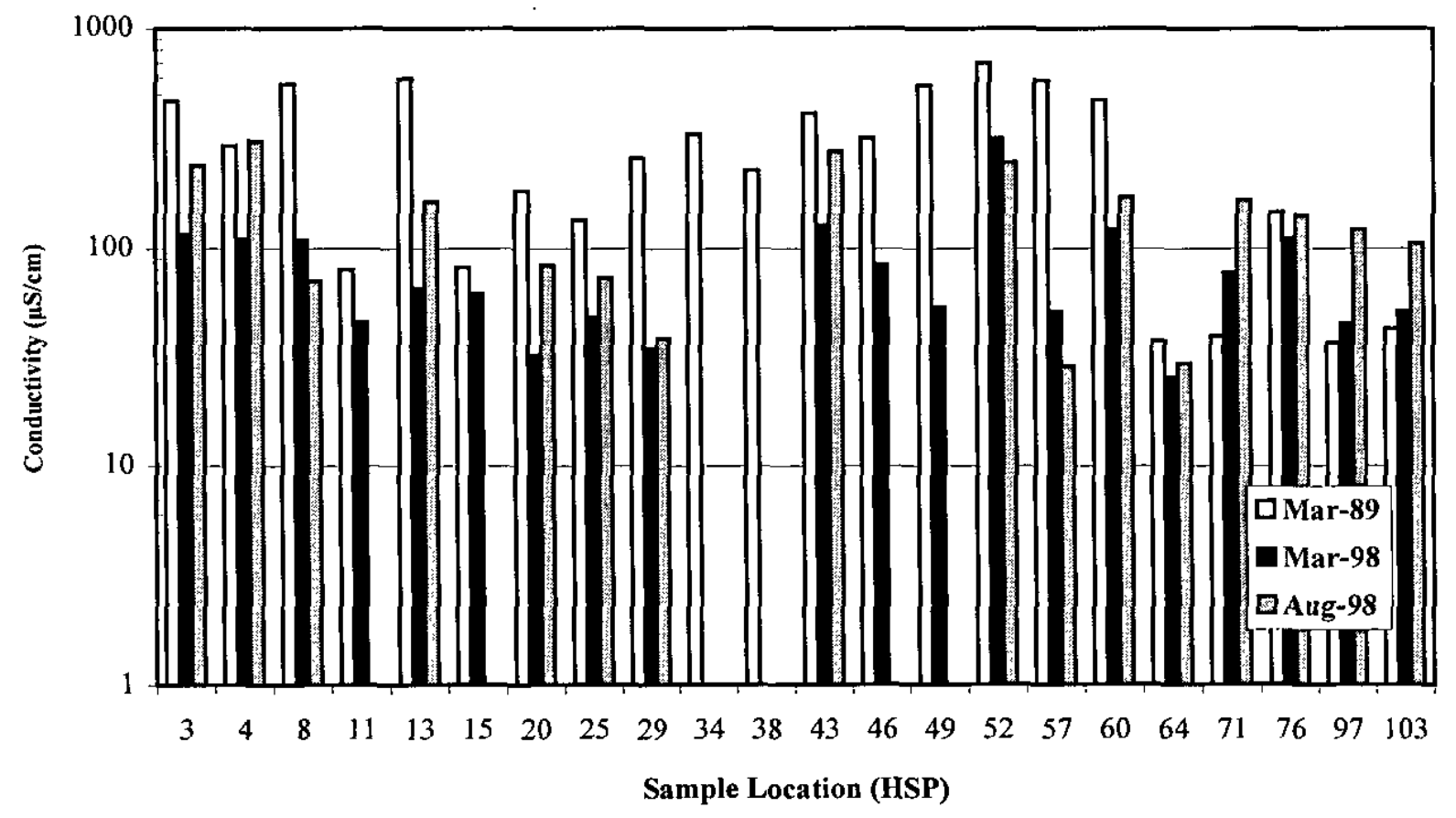

Figure 12. Comparison of Specific Electrical Conductivity at H-Area Seepline Locations. 


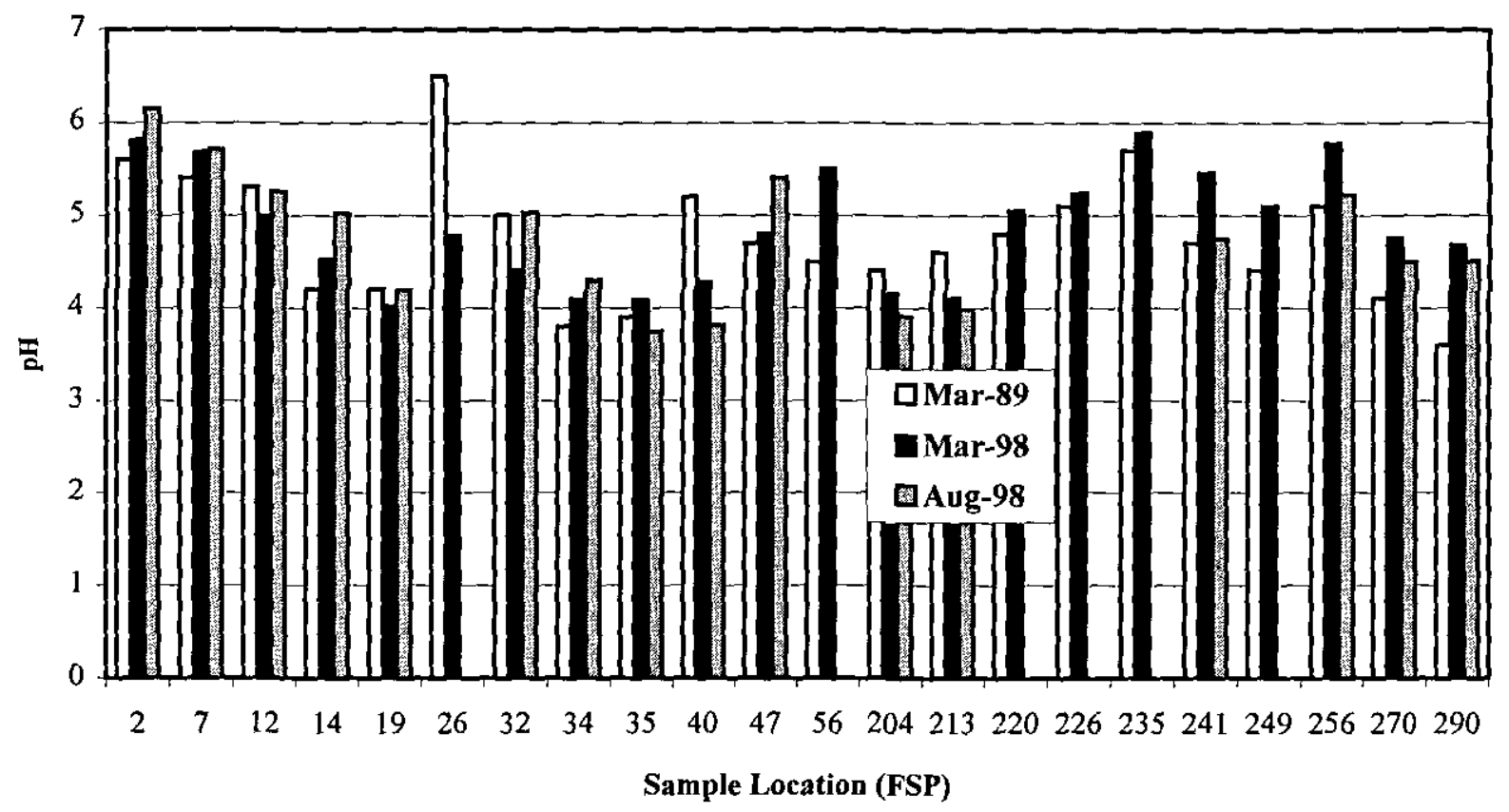

Figure 13. Comparison of $\mathrm{pH}$ at F-Area Seepline Locations.

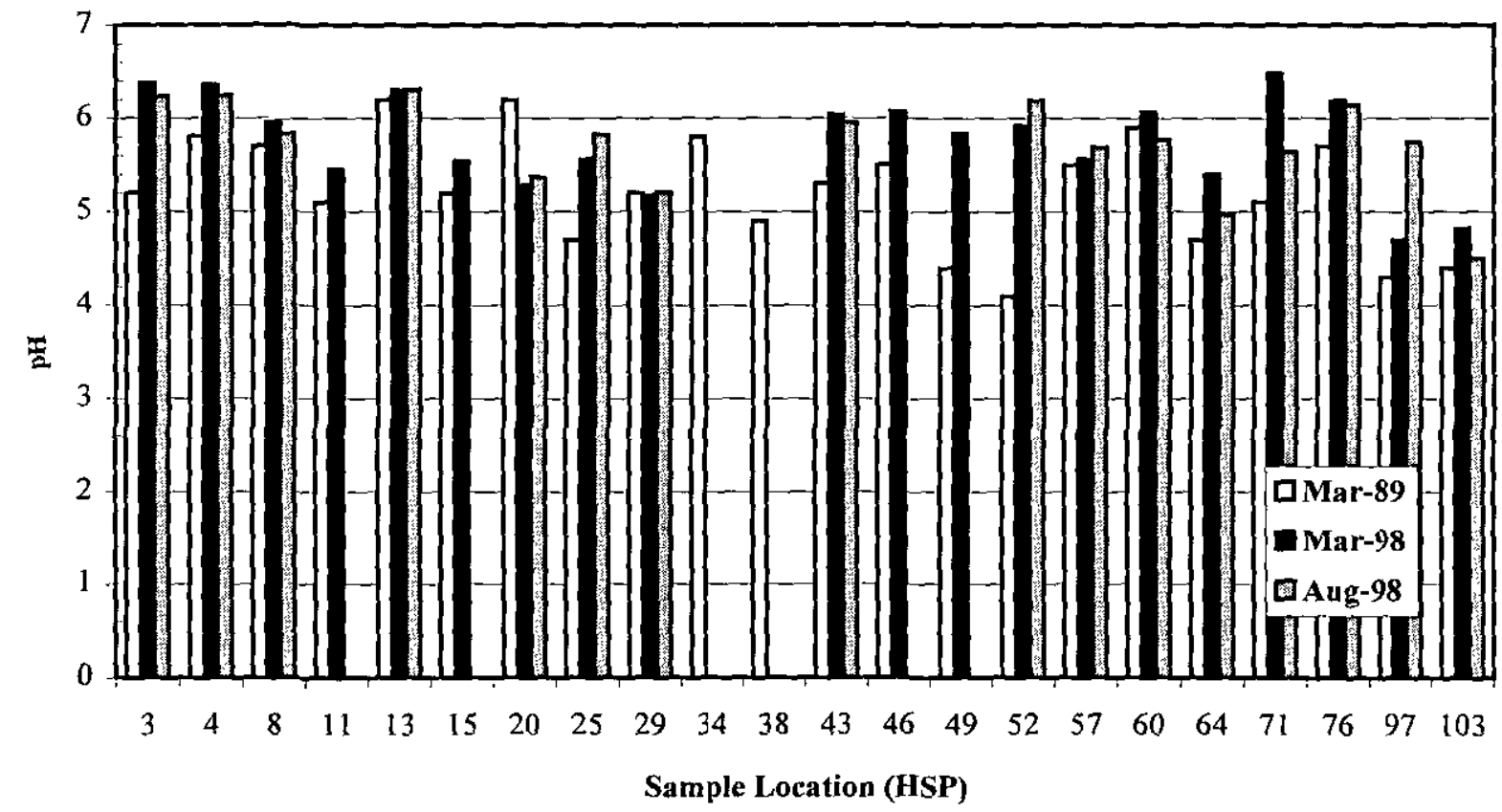

Figure 14. Comparison of $\mathrm{pH}$ at $\mathrm{H}-\mathrm{Area}$ Seepline Locations. 
Results of the Tritium Survey in the $F$ and $H$ Area Seepline and Fourmile Branch at SRS: March 1998 and August 1998 Sampling Events and 1989-1998 Summary

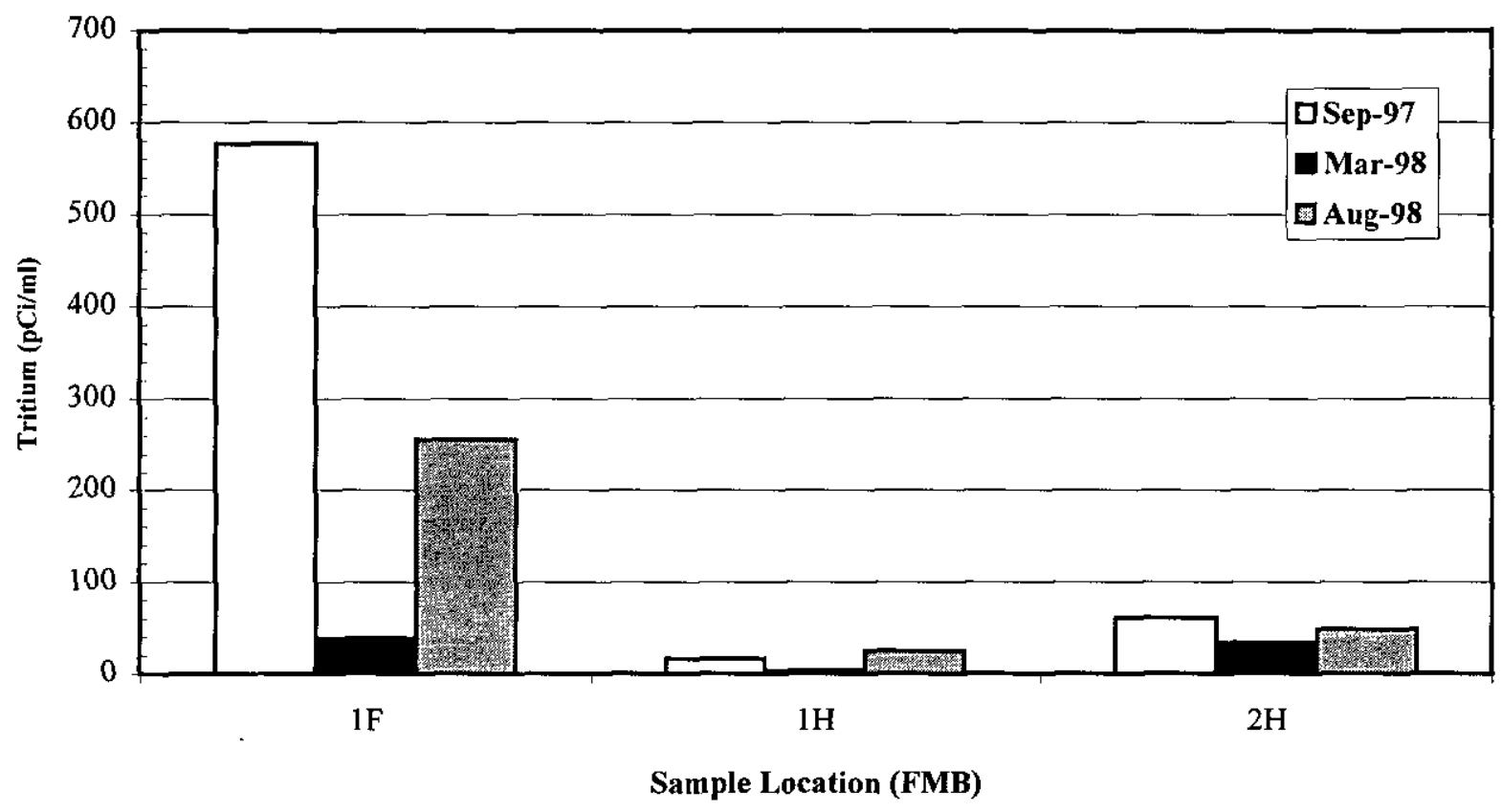

Figure 15. Comparison of Tritium Concentrations at Fourmile Branch Locations.

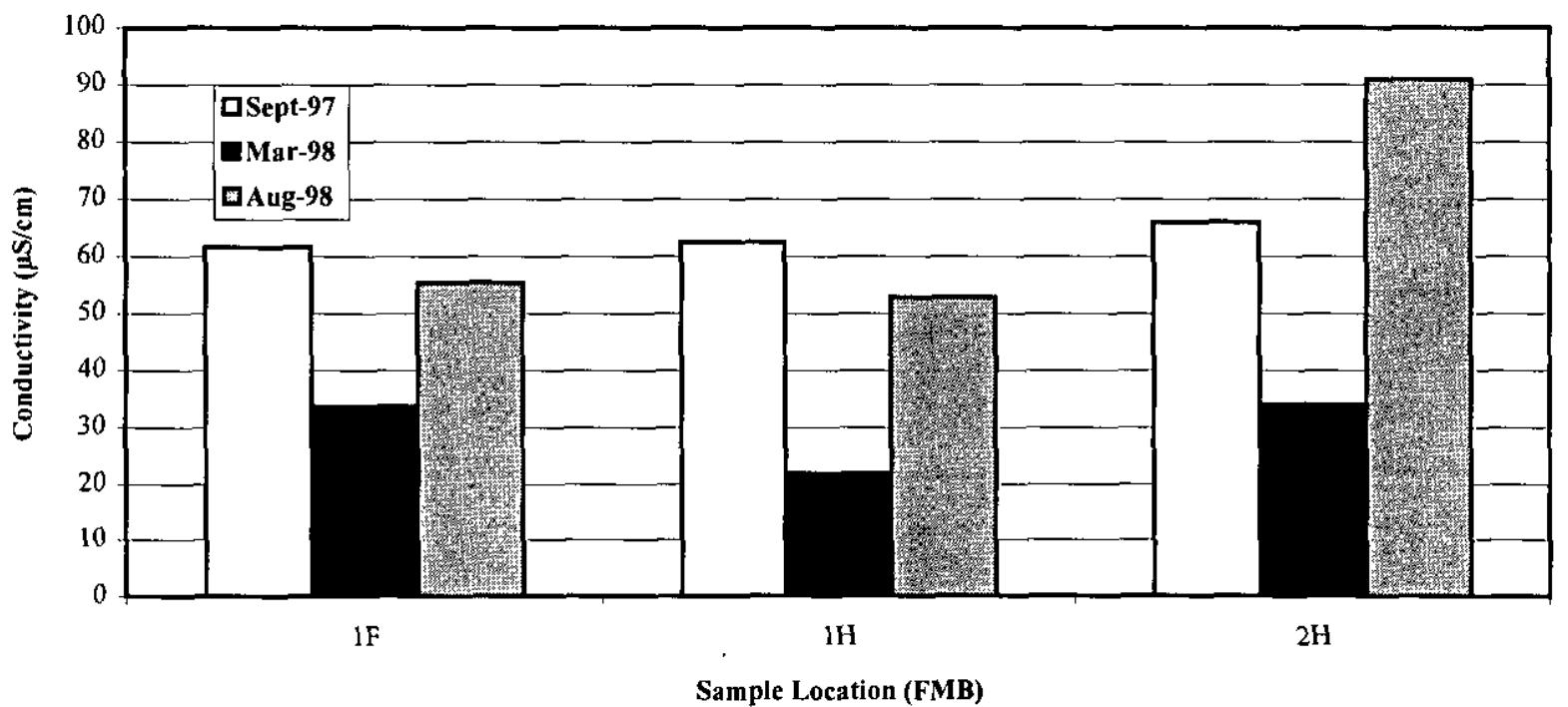

Figure 16. Comparison of Specific Electric Conductivity at Fourmile Branch Locations. 


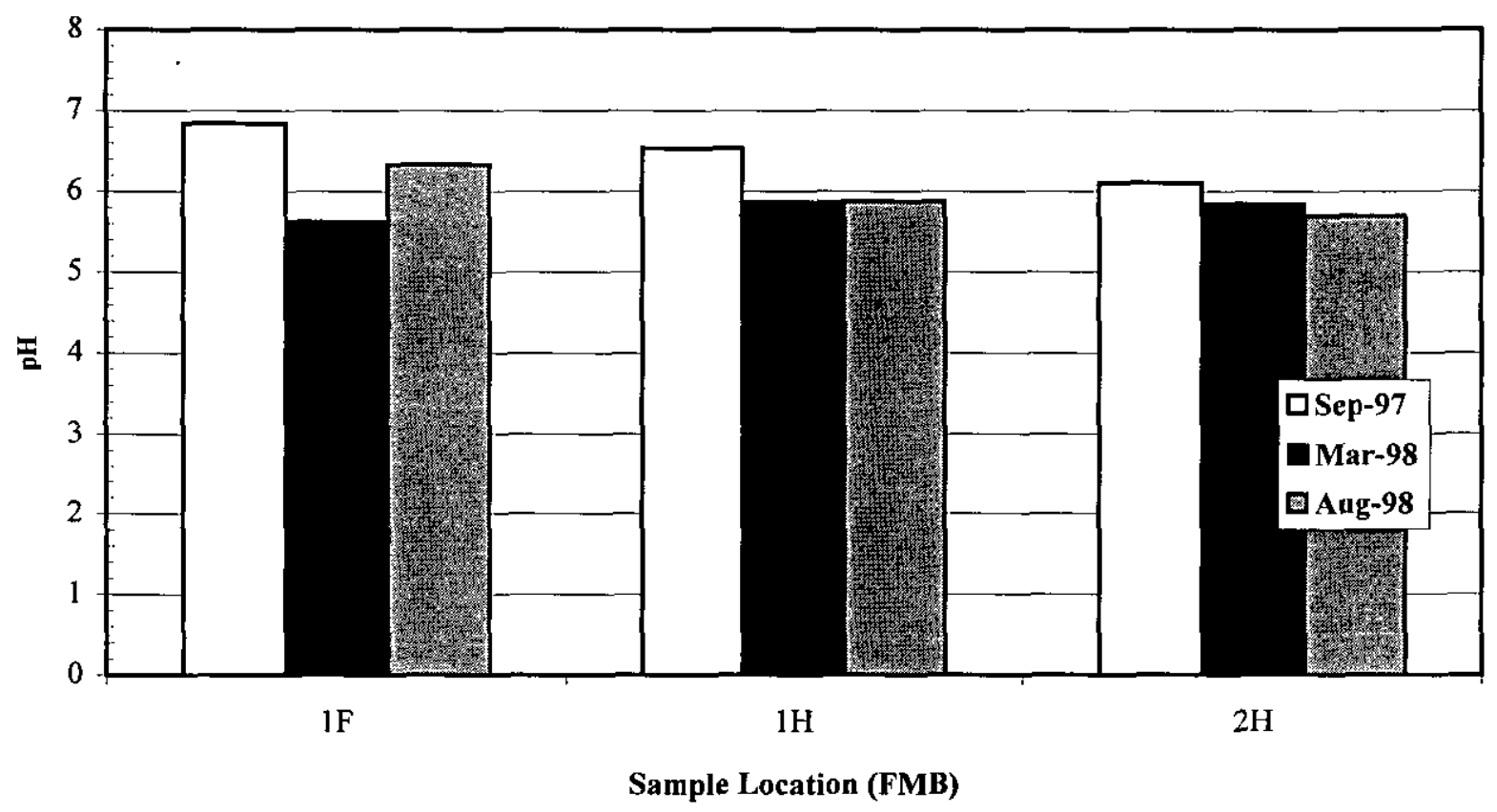

Figure 17. Comparison of $\mathrm{pH}$ at Fourmile Branch Locations.

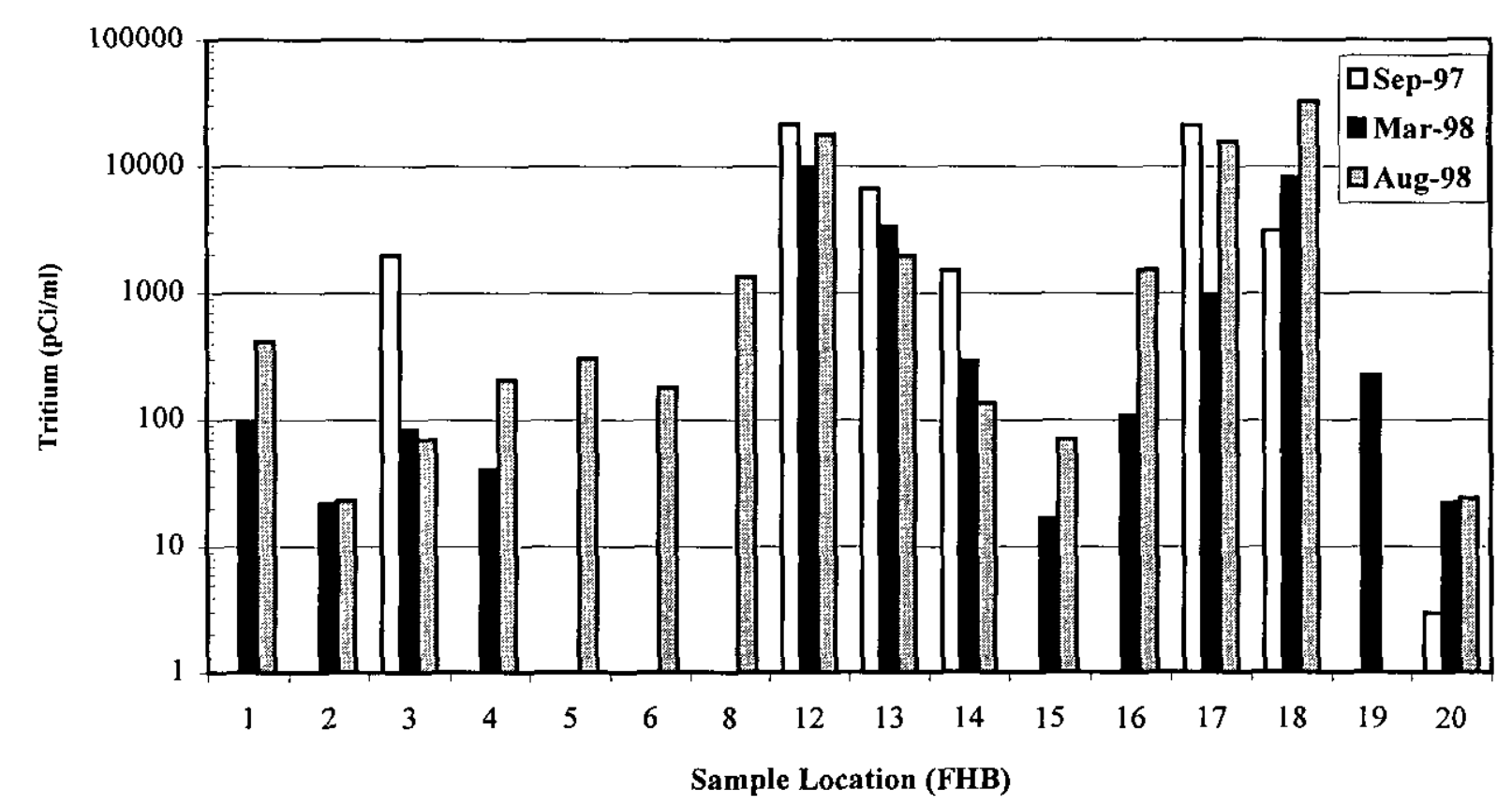

Figure 18. Comparison of Tritium Concentrations at Locations on the Seepline South of 643-E. 
Results of the Tritium Survey in the $F$ and $H$ Area Seepline and Fourmile Branch at SRS: March 1998 and August 1998 Sampling Events and 1989-1998 Summary

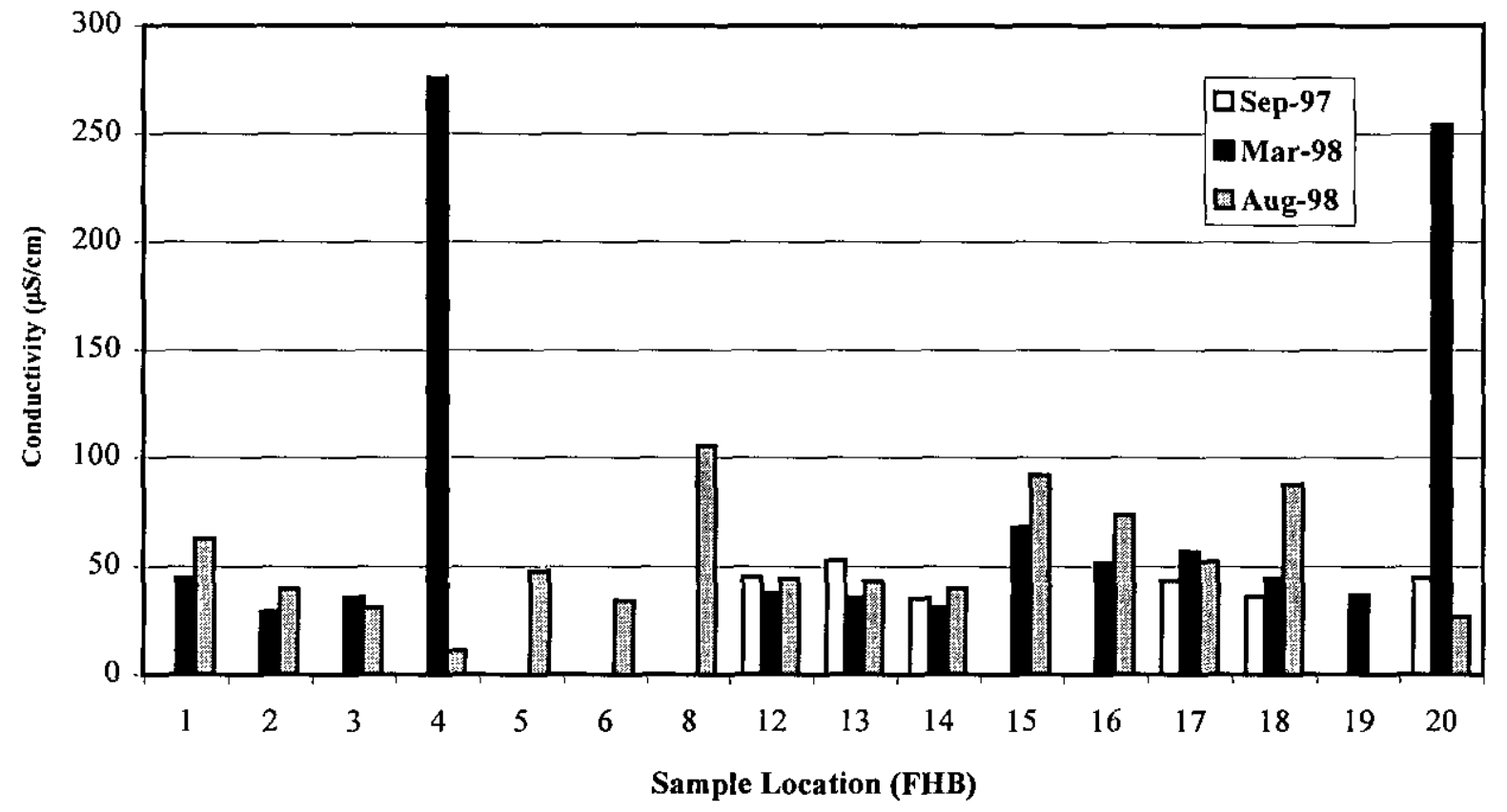

Figure 19. Comparison of Conductivity at Locations on the Seepline South of 643-E

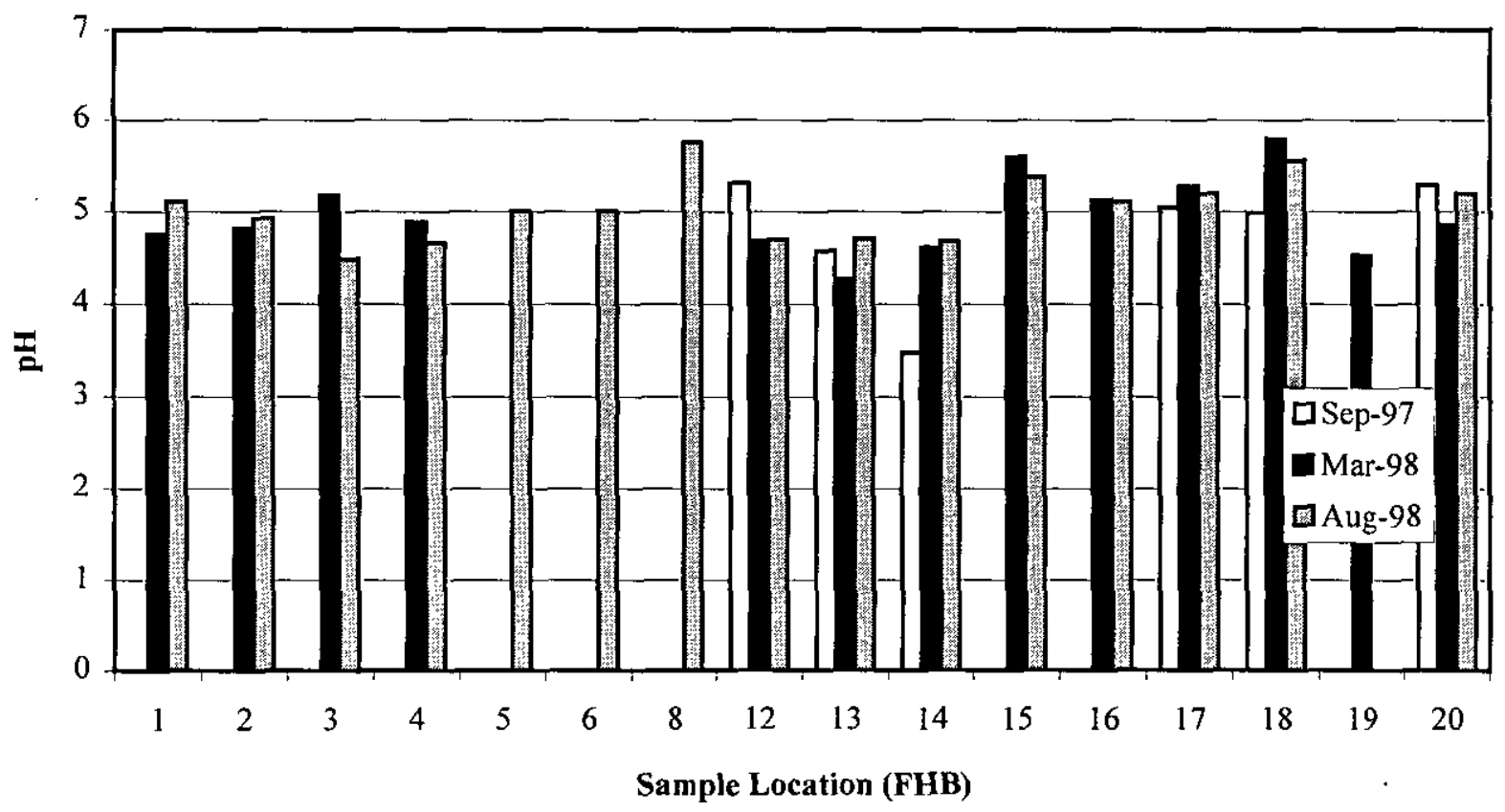

Figure 20. Comparison of $\mathrm{pH}$ at Locations on the Seepline South of 643-E 


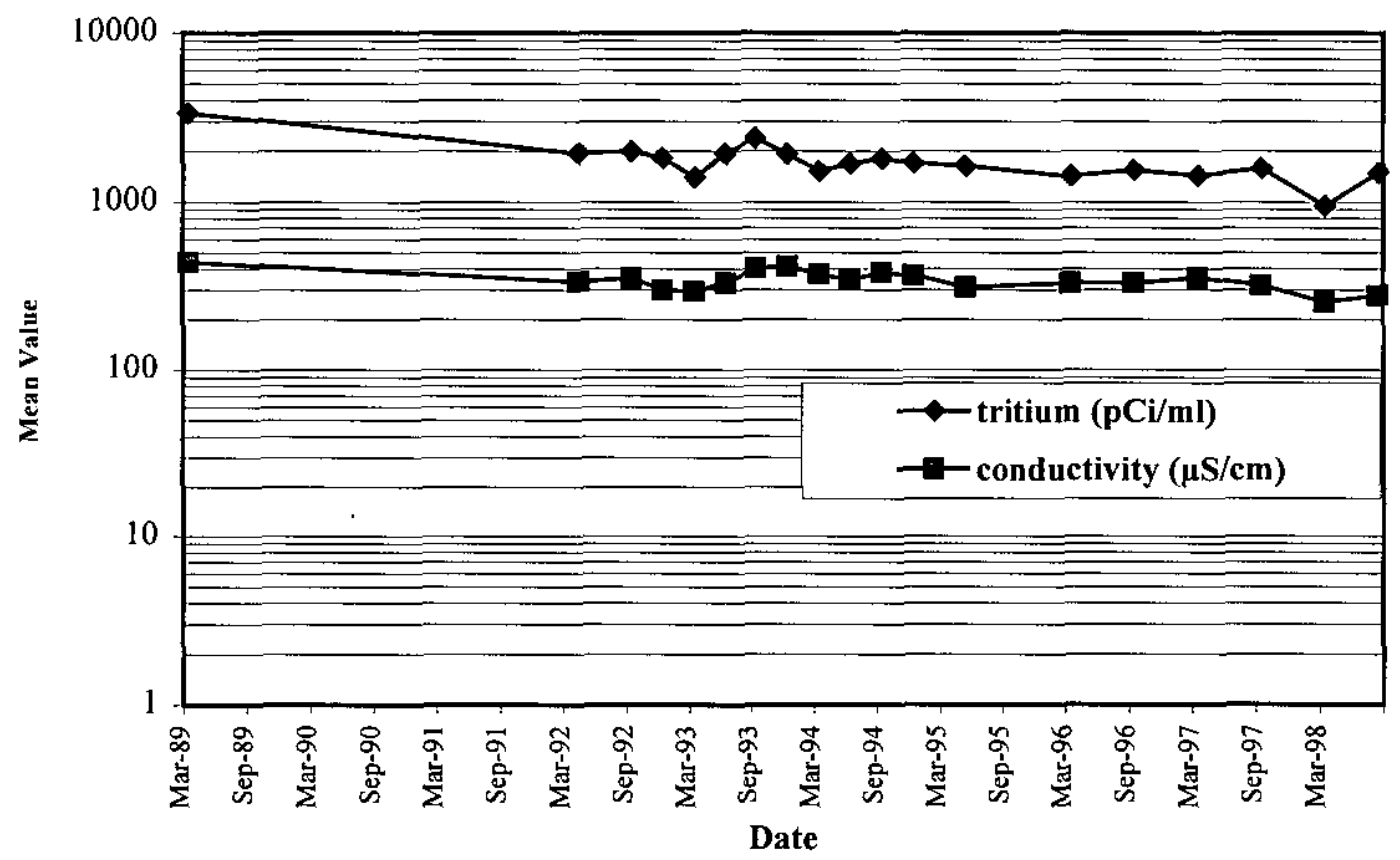

Figure 21. Tritium and Conductivity Trends for F-Area Seepline. Each point represents the mean value of a sampling event.

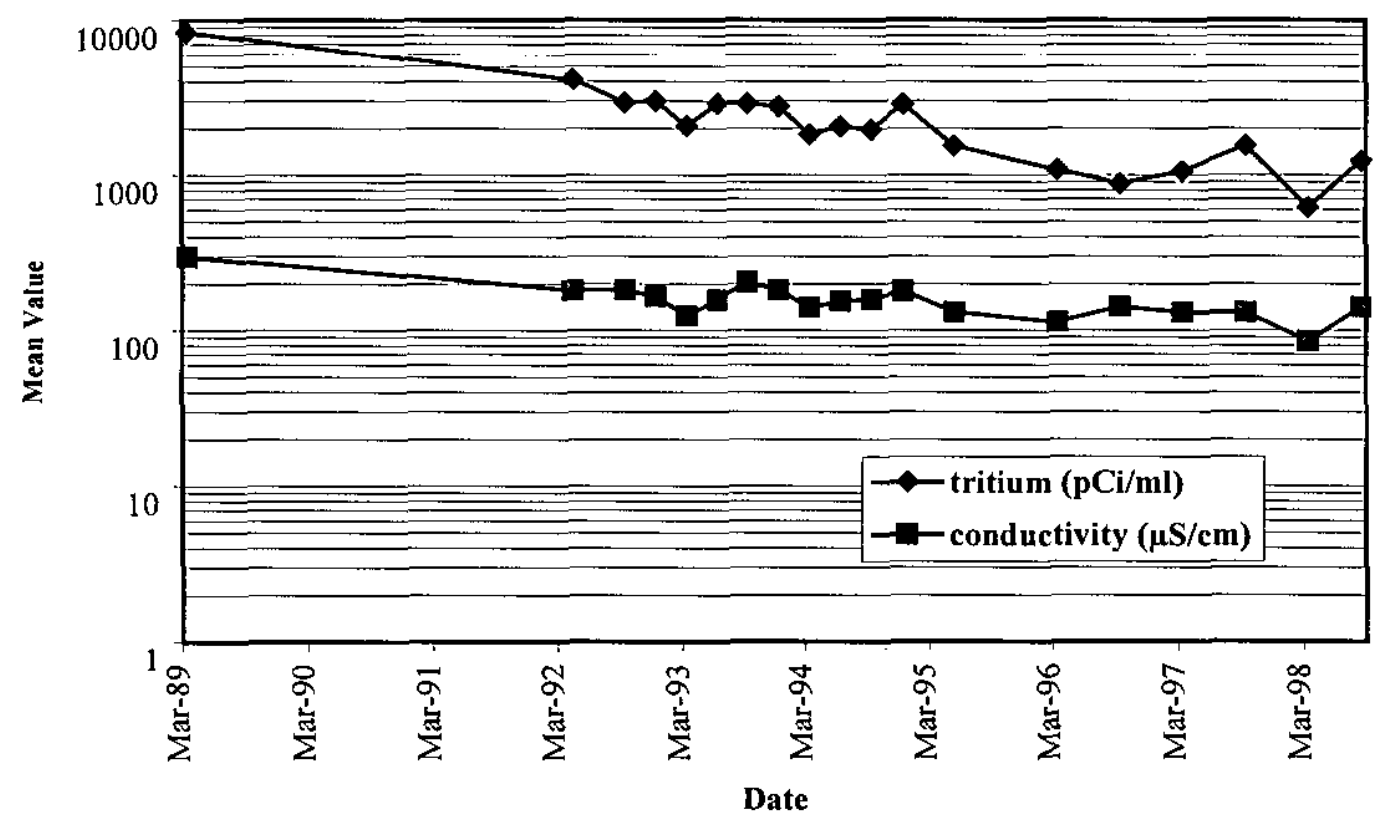

Figure 22. Tritium and Conductivity Trends for H-Area Seepline. Each point represents the mean value of a sampling event. 
Results of the Tritium Survey in the $F$ and $H$ Area Seepline and Fourmile Branch at SRS: March 1998 and August 1998 Sampling Events and 1989-1998 Summary

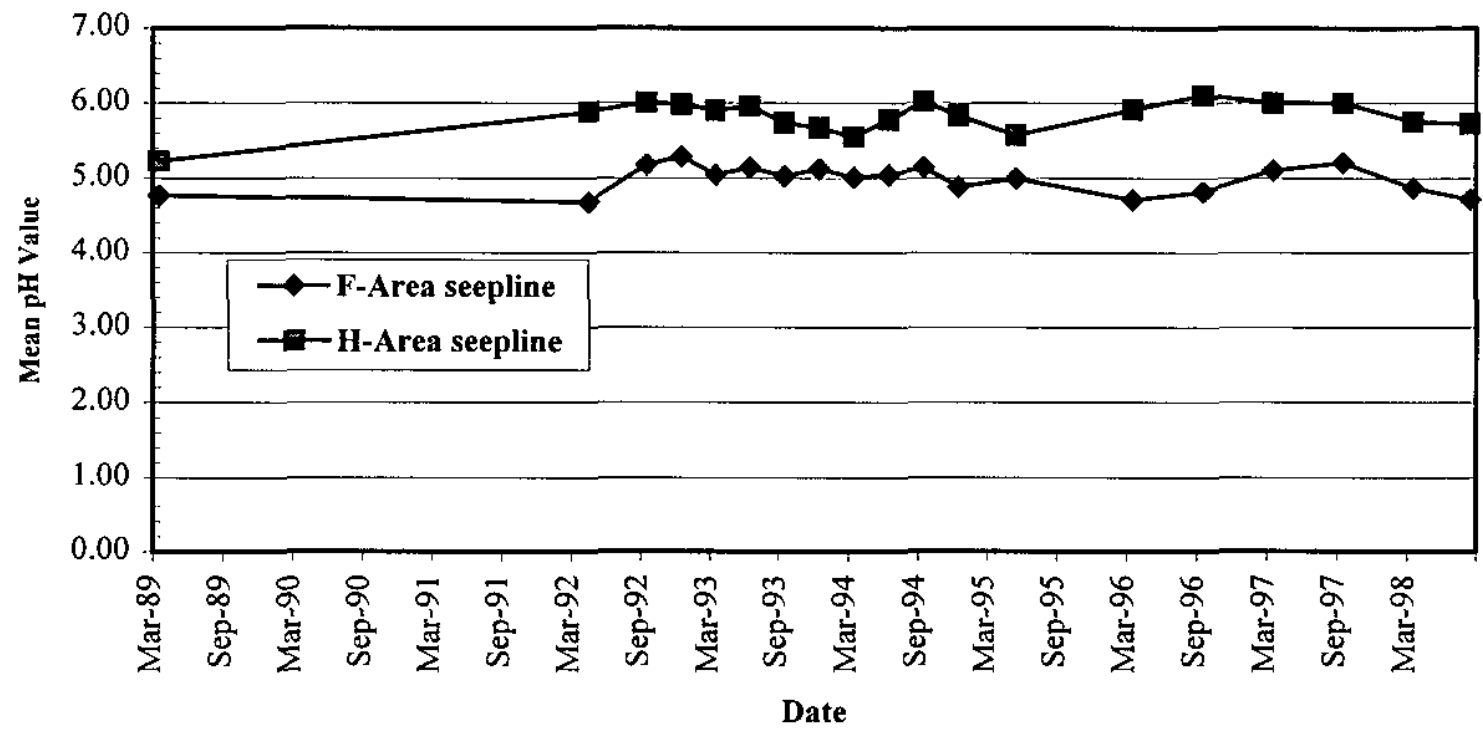

Figure 23. $\quad \mathrm{pH}$ Trends for F- and H-Area Seeplines. Each point represents the mean value of a sampling event.

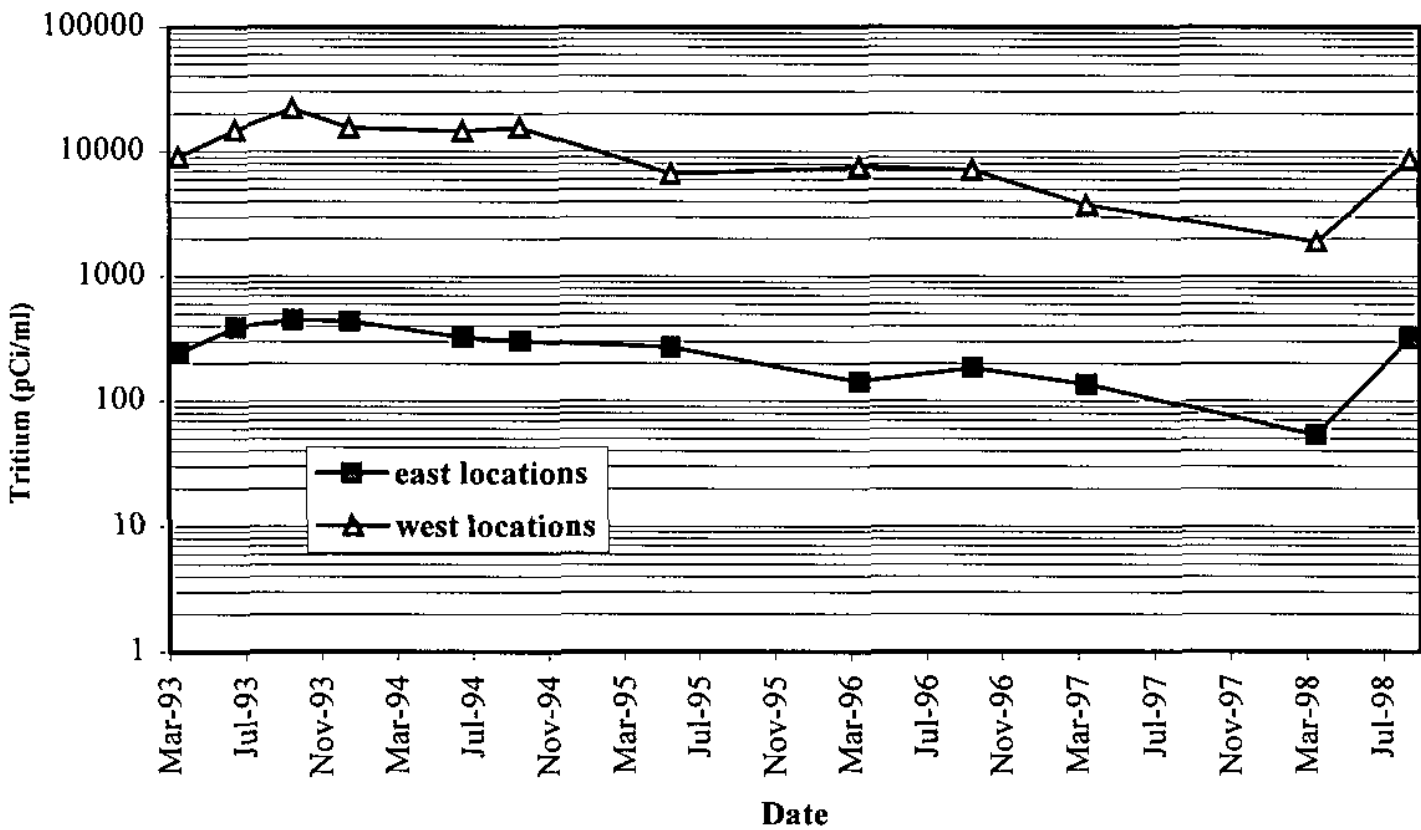

Figure 24. Comparison of tritium concentrations for Seepline below 643-E. Each point represents the mean value of a sampling event. Note: September 1997 was omitted since 14 dry locations were encountered during the sampling event. 


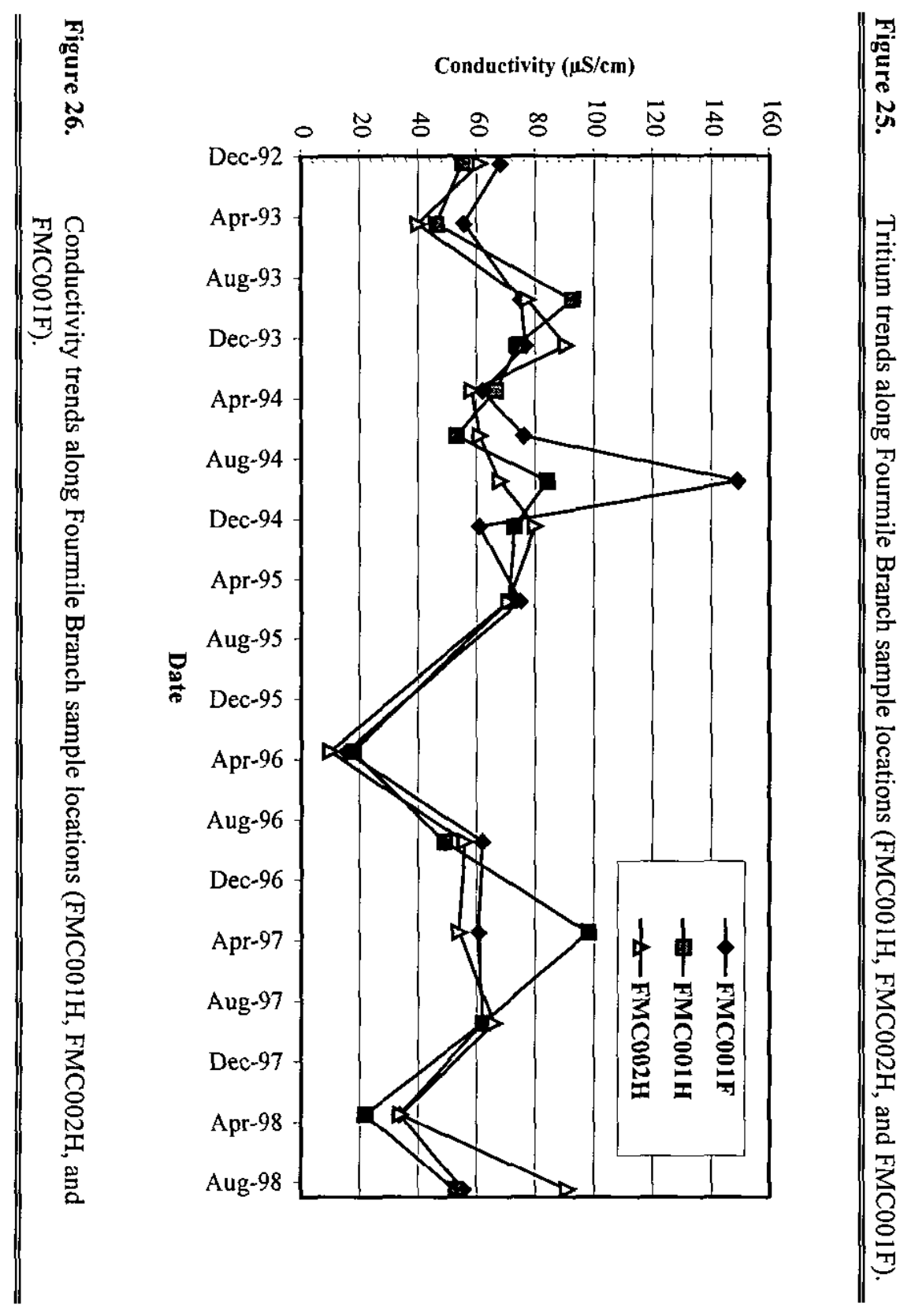


Results of the Tritium Survey in the $F$ and $H$ Area Seepline and Fourmile Branch at SRS: March 1998 and August 1998 Sampling Events and 1989-1998 Summary

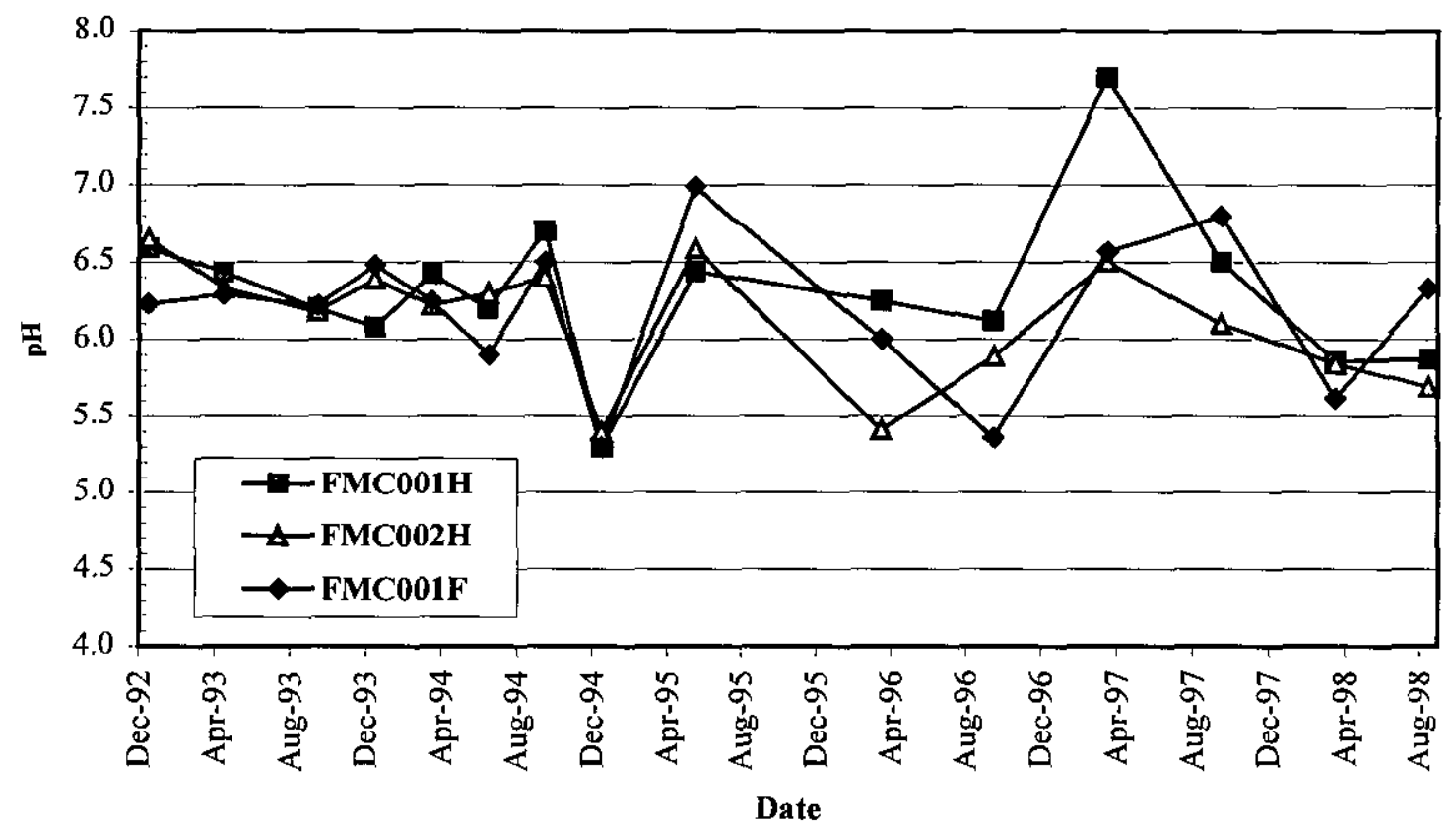

Figure 27. $\quad \mathrm{pH}$ trends along Fourmile Branch sample locations (FMC001H, FMC002H, and FMC001F).

Table 3. Comparison of 1997/98 Rainfall to the Long-term Monthly Average from the F-Area Weather Station.

\begin{tabular}{|c|c|c|c|}
\hline Month & Year & $\begin{array}{c}\text { Rainfall (cm), F-Area Weather } \\
\text { Station, (Sept.1997-Aug.1998) }\end{array}$ & $\begin{array}{c}\text { Long-term Rainfall (cm), F-Area } \\
\text { Weather Station, (1961-1994) }\end{array}$ \\
\hline Sept & 1997 & 14.73 & 8.77 \\
\hline Oct & 1997 & 14.07 & 7.80 \\
\hline Nov & 1997 & 13.92 & 7.12 \\
\hline Dec & 1997 & 19.23 & 8.97 \\
\hline Jan & 1998 & 20.98 & 11.14 \\
\hline Feb & 1998 & 16.74 & 10.74 \\
\hline Mar & 1998 & 16.51 & 12.62 \\
\hline April & 1998 & 15.19 & 8.01 \\
\hline May & 1998 & 9.22 & 9.31 \\
\hline June & 1998 & 9.47 & 11.77 \\
\hline July & 1998 & 12.17 & 13.97 \\
\hline Dec-Feb rainfall & $\mathbf{5 6 . 9 5}$ & $\mathbf{3 0 . 8 5}$ \\
\hline May-July rainfall & $\mathbf{3 0 . 8 6}$ & $\mathbf{3 5 . 0 4}$ \\
\hline
\end{tabular}


Table 4. Comparison of F-Area Seepline Measurements (Tritium, Conductivity, and $\mathrm{pH}$ ) for the March 1989, March 1998, and August 1998 Sampling Events.

\begin{tabular}{|c|c|c|c|c|c|c|c|c|c|}
\hline & \multicolumn{2}{|c|}{ Tritium (pCi/ml) } & \multicolumn{2}{c|}{ Conductivity ( $\boldsymbol{\mu S / c m})$} & \multicolumn{3}{c|}{ pH(-log H) } \\
\hline Location & Mar-89 & Mar-98 & Aug-98 & Mar-89 & Mar-98 & Aug-98 & Mar-89 & Mar-98 & Aug-98 \\
\hline 2 & 520 & 278 & 699 & 95 & 42 & 84 & 5.6 & 5.8 & 6.2 \\
\hline 7 & 3400 & 303 & 2050 & 681 & 86 & 230 & 5.4 & 5.7 & 5.7 \\
\hline 12 & 260 & 11 & 129 & 30 & 35 & 23 & 5.3 & 5.0 & 5.3 \\
\hline 14 & 14000 & 27 & 266 & 666 & 32 & 35 & 4.2 & 4.5 & 5.0 \\
\hline 19 & 4900 & 1080 & 2570 & 1424 & 1018 & 637 & 4.2 & 4.0 & 4.2 \\
\hline 26 & 4400 & 5160 & dry & 1095 & 909 & dry & 6.5 & 4.8 & dry \\
\hline 32 & 3600 & 52 & 87 & 174 & 39 & 41 & 5.0 & 4.4 & 5.0 \\
\hline 34 & 14000 & 1240 & 1550 & 810 & 327 & 410 & 3.8 & 4.1 & 4.3 \\
\hline 35 & 11000 & 4670 & 8570 & 1100 & 954 & 1176 & 3.9 & 4.1 & 3.7 \\
\hline 40 & 7800 & 3290 & 3530 & 900 & 730 & 666 & 5.2 & 4.3 & 3.8 \\
\hline 47 & 100 & 32 & 75 & 52 & 324 & 27 & 4.7 & 4.8 & 5.4 \\
\hline 56 & 19 & 14 & dry & 34 & 35 & dry & 4.5 & 5.5 & dry \\
\hline 204 & 3000 & 1370 & 2510 & 895 & 273 & 448 & 4.4 & 4.2 & 3.9 \\
\hline 213 & 2800 & 641 & 1330 & 860 & 222 & 249 & 4.6 & 4.1 & 4.0 \\
\hline 220 & 560 & 1290 & dry & 147 & 134 & dry & 4.8 & 5.1 & dry \\
\hline 226 & 1300 & 170 & dry & 306 & 109 & dry & 5.1 & 5.2 & dry \\
\hline 235 & 580 & 122 & dry & 84 & 54 & dry & 5.7 & 5.9 & dry \\
\hline 241 & 560 & 853 & 10 & 36 & 82 & 258 & 4.7 & 5.5 & 4.7 \\
\hline 249 & 580 & 64 & dry & 84 & 64 & dry & 4.4 & 5.1 & dry \\
\hline 256 & 400 & 113 & 397 & 56 & 42 & 84 & 5.1 & 5.8 & 5.2 \\
\hline 270 & 40 & 30 & 36 & 50 & 34 & 31 & 4.1 & 4.8 & 4.5 \\
\hline 290 & 35 & 32 & 60 & 49 & 24 & 28 & 3.6 & 4.7 & 4.5 \\
\hline
\end{tabular}

Table 5. Comparison of Fourmile Branch Measurements (Tritium, Conductivity, and $\mathrm{pH}$ ) for the September 1997, March 1998, and August 1998 Sampling Events.

\begin{tabular}{|c|c|c|c|c|c|c|c|c|c|}
\hline Sample & \multicolumn{3}{|c|}{ Tritium (pCi/ml) } & \multicolumn{3}{c|}{ Conductivity $(\boldsymbol{\mu S} / \mathbf{c m})$} & \multicolumn{3}{c|}{ pH (-log H) } \\
\hline Location & Sep-97 & Mar-98 & Aug-98 & Sep-97 & Mar-98 & Aug-98 & Sep-97 & Mar-98 & Aug-98 \\
\hline 1F & 577 & 39 & 256 & 62 & 34 & 55 & 6.8 & 5.6 & 6.3 \\
\hline 1H & 16 & 3 & 25 & 62 & 22 & 53 & 6.5 & 5.9 & 5.9 \\
\hline 2H & 61 & 34 & 48 & 66 & 34 & 91 & 6.1 & 5.8 & 5.7 \\
\hline
\end{tabular}


Results of the Tritium Survey in the F and $\mathrm{H}$ Area Seepline and Fourmile Branch at SRS: March 1998 and August 1998 Sampling Events and 1989-1998 Summary

Table 6. Comparison of H-Area Seepline Measurements (Tritium, Conductivity, and $\mathrm{pH}$ ) for the March 1989, March 1998, and August 1998 Sampling Events.

\begin{tabular}{|c|c|c|c|c|c|c|c|c|c|}
\hline & \multicolumn{3}{|c|}{ Tritium (pCi/ml) } & \multicolumn{3}{c|}{ Conductivity $(\boldsymbol{\mu S}$ /cm) } & \multicolumn{3}{c|}{ pH (-log H) } \\
\hline Location & Mar-89 & Mar-98 & Aug-98 & Mar-89 & Mar-98 & Aug-98 & Mar-89 & Mar-98 & Aug-98 \\
\hline 3 & 14000 & 270 & 827 & 468 & 116 & 239 & 5.2 & 6.4 & 6.2 \\
\hline 4 & 11000 & 288 & 317 & 292 & 110 & 308 & 5.8 & 6.4 & 6.2 \\
\hline 8 & 24000 & 658 & 499 & 556 & 110 & 71 & 5.7 & 6.0 & 5.8 \\
\hline 11 & 960 & 42 & dry & 80 & 47 & dry & 5.1 & 5.5 & dry \\
\hline 13 & 12000 & 230 & 494 & 592 & 66 & 163 & 6.2 & 6.3 & 6.3 \\
\hline 15 & 1000 & 142 & dry & 82 & 62 & dry & 5.2 & 5.5 & dry \\
\hline 20 & 6500 & 42 & 70 & 183 & 33 & 84 & 6.2 & 5.3 & 5.4 \\
\hline 25 & 3300 & 171 & 231 & 135 & 49 & 74 & 4.7 & 5.6 & 5.8 \\
\hline 29 & 9200 & 27 & 39 & 257 & 35 & 39 & 5.2 & 5.2 & 5.2 \\
\hline 34 & 5600 & dry & dry & 331 & dry & dry & 5.8 & dry & dry \\
\hline 38 & 6500 & dry & dry & 227 & dry & dry & 4.9 & dry & dry \\
\hline 43 & 10000 & 1030 & 2240 & 413 & 128 & 276 & 5.3 & 6.0 & 6.0 \\
\hline 46 & 11000 & 458 & dry & 318 & 84 & dry & 5.5 & 6.1 & dry \\
\hline 49 & 11000 & 61 & dry & 551 & 54 & dry & 4.4 & 5.8 & dry \\
\hline 52 & 20000 & 6200 & 6100 & 699 & 316 & 246 & 4.1 & 5.9 & 6.2 \\
\hline 57 & 15000 & 97 & 8 & 581 & 52 & 29 & 5.5 & 5.6 & 5.7 \\
\hline 60 & 21000 & 319 & 3090 & 473 & 123 & 171 & 5.9 & 6.1 & 5.8 \\
\hline 64 & 320 & 21 & 39 & 38 & 26 & 30 & 4.7 & 5.4 & 5.0 \\
\hline 71 & 450 & 858 & 2090 & 40 & 78 & 167 & 5.1 & 6.5 & 5.6 \\
\hline 76 & 400 & 110 & 292 & 146 & 111 & 142 & 5.7 & 6.2 & 6.1 \\
\hline 97 & 1100 & 796 & 1660 & 37 & 46 & 123 & 4.3 & 4.7 & 5.7 \\
\hline 103 & 510 & 530 & 1670 & 43 & 52 & 105 & 4.4 & 4.8 & 4.5 \\
\hline
\end{tabular}


Table 7. Comparison of 643-E Seepline Measurements (Tritium, Conductivity, and $\mathrm{pH}$ ) for the September 1997, March 1998, and August 1998 Sampling Events.

\begin{tabular}{|c|c|c|c|c|c|c|c|c|c|}
\hline & \multicolumn{3}{|c|}{ Tritium (pCi/ml) } & \multicolumn{3}{c|}{ Conductivity $(\mu \mathrm{S} / \mathrm{cm})$} & \multicolumn{3}{c|}{ pH (-log H) } \\
\hline Location & Sep-97 & Mar-98 & Aug-98 & Sep-97 & Mar-98 & Aug-98 & Sep-97 & Mar-98 & Aug-98 \\
\hline $\mathbf{l}$ & dry & 98 & 413 & dry & 45 & 63 & dry & 4.8 & 5.1 \\
\hline 2 & dry & 22 & 23 & dry & 29 & 40 & dry & 4.8 & 4.9 \\
\hline $\mathbf{3}$ & 1960 & 83 & 70 & na & 36 & 31 & na & 5.2 & 4.5 \\
\hline 4 & dry & 40 & 205 & dry & 276 & 11 & dry & 4.9 & 4.7 \\
\hline 5 & dry & dry & 304 & dry & dry & 48 & dry & dry & 5.0 \\
\hline 6 & dry & dry & $\mathbf{1 8 1}$ & dry & dry & 34 & dry & dry & 5.0 \\
\hline $\mathbf{8}$ & dry & dry & 1320 & dry & dry & 106 & dry & dry & 5.8 \\
\hline $\mathbf{1 2}$ & 21300 & 9840 & 17800 & 45 & 38 & 44 & 5.3 & 4.7 & 4.7 \\
\hline $\mathbf{1 3}$ & 6660 & 3330 & 1960 & 53 & 36 & 43 & 4.6 & 4.3 & 4.7 \\
\hline $\mathbf{1 4}$ & 1500 & 291 & 136 & 35 & 31 & 40 & 3.5 & 4.6 & 4.7 \\
\hline 15 & dry & 17 & 71 & dry & $\mathbf{6 8}$ & 92 & dry & 5.6 & 5.4 \\
\hline 16 & dry & 110 & 1520 & dry & 52 & 74 & dry & 5.1 & 5.1 \\
\hline $\mathbf{1 7}$ & 21100 & 972 & 15700 & 43 & 57 & 52 & 5.1 & 5.3 & 5.2 \\
\hline $\mathbf{1 8}$ & 3100 & $\mathbf{8 1 8 0}$ & 32300 & 36 & 45 & 88 & 5.0 & 5.8 & 5.6 \\
\hline 19 & dry & 223 & dry & dry & 37 & dry & dry & 4.5 & dry \\
\hline $\mathbf{2 0}$ & 3 & 23 & 24 & 45 & 254 & 27 & 5.3 & 4.9 & 5.2 \\
\hline
\end{tabular}

Table 8. Average Tritium, conductivity and $\mathrm{pH}$ values for Sampling Events (1989 through 1998) at the $\mathrm{F}$ and $\mathrm{H}$-Area Seeplines.

\begin{tabular}{|c|c|c|c||c|c|c|}
\hline Sample & \multicolumn{2}{|c||}{ F Area Seepline-Average Values } & \multicolumn{3}{|c|}{ H Area Seepline-Average Values } \\
\hline Date & tritium $(\mathrm{pCi} / \mathbf{m l})$ & Conductivity $(\mu \mathrm{S} / \mathbf{c m})$ & $\mathbf{p H}$ & tritium $(\mathbf{p C i} / \mathbf{m l})$ & Conductivity $(\mu \mathrm{S} / \mathbf{c m})$ & $\mathbf{p H}$ \\
\hline Mar-89 & 3357 & 438 & 4.8 & 8402 & 297 & 5.2 \\
\hline Apr-92 & 1934 & 335 & 4.7 & 4131 & 183 & 5.9 \\
\hline Sep-92 & 1990 & 352 & 5.2 & 2904 & 182 & 6.0 \\
\hline Dec-92 & 1823 & 300 & 5.3 & 3001 & 165 & 6.0 \\
\hline Mar-93 & 1398 & 293 & 5.0 & 2063 & 124 & 5.9 \\
\hline Jun-93 & 1936 & 330 & 5.1 & 2885 & 157 & 6.0 \\
\hline Sep-93 & 2384 & 404 & 5.0 & 2876 & 205 & 5.7 \\
\hline Dec-93 & 1920 & 415 & 5.1 & 2749 & 181 & 5.7 \\
\hline Mar-94 & 1525 & 371 & 5.0 & 1818 & 140 & 5.6 \\
\hline Jun-94 & 1688 & 344 & 5.0 & 2053 & 153 & 5.8 \\
\hline Sep-94 & 1806 & 381 & 5.1 & 1953 & 159 & 6.0 \\
\hline Dec-94 & 1698 & 366 & 4.9 & 2836 & 179 & 5.8 \\
\hline May-95 & 1634 & 311 & 5.0 & 1547 & 131 & 5.6 \\
\hline Mar-96 & 1424 & 331 & 4.7 & 1082 & 113 & 5.9 \\
\hline Sep-96 & 1545 & 328 & 4.8 & 880 & 142 & 6.1 \\
\hline Mar-97 & 1431 & 354 & 5.1 & 1057 & 130 & 6.0 \\
\hline Sep-97 & 1576 & 320 & 5.2 & 1539 & 130 & 6.0 \\
\hline Mar-98 & 947 & 253 & 4.9 & 618 & 85 & 5.8 \\
\hline Aug-98 & 1492 & 277 & 4.7 & 1229 & 142 & 5.7 \\
\hline
\end{tabular}


Results of the Tritium Survey in the F and $H$ Area Seepline and Fourmile Branch at SRS: March 1998 and August 1998 Sampling Events and 1989-1998 Summary

Table 9. Average Tritium, and Conductivity Values for Sampling Events (1993 through 1998) at the 643-E Seepline.

\begin{tabular}{|c|c|c|c|c|c|c|}
\hline Sample & \multicolumn{2}{|c|}{ Tritium Concentration (pCi/ml) } & \multicolumn{3}{|c|}{ Conductivity $(\boldsymbol{\mu S} / \mathrm{cm})$} \\
\hline Date & (all) & (East) & (West) & (All) & ( East) & (West) \\
\hline Mar-93 & 4808 & 242 & 8999 & 62 & 43 & 88 \\
\hline Jun-93 & 7617 & 389 & 14779 & 82 & 53 & 122 \\
\hline Sep-93 & 10924 & 445 & 22017 & 92 & 57 & 140 \\
\hline Dec-93 & 8182 & 435 & 15527 & 68 & 56 & 86 \\
\hline Jun-94 & 8557 & 324 & 14557 & 58 & 53 & 68 \\
\hline Sep-94 & 8065 & 303 & 15469 & 57 & 53 & 65 \\
\hline May-95 & 4323 & 270 & 6630 & 69 & 64 & 79 \\
\hline Mar-96 & 4069 & 143 & 7483 & 43 & 36 & 53 \\
\hline Sep-96 & 4260 & 183 & 7121 & 44 & 37 & 54 \\
\hline Mar-97 & 2730 & 136 & 3760 & 45 & 38 & 55 \\
\hline Sept-97* & $\mathbf{7 9 4 6 ^ { * }}$ & $\mathbf{9 8 1 *}$ & $\mathbf{8 0 9 0 ^ { * }}$ & 43 & 45 & 42 \\
\hline Mar-98 & 1787 & 53 & 1875 & 77 & 128 & 46 \\
\hline Aug-98 & 4802 & 317 & 8614 & 53 & 45 & 65 \\
\hline
\end{tabular}

*Note: There were nine dry sample locations during this sampling event. 
Table 10. Average Tritium Values for Sampling Events (1992 through 1998) Along Fourmile Branch.

\begin{tabular}{|c|c|c|c|c||c|}
\hline $\begin{array}{c}\text { Sample } \\
\text { Date }\end{array}$ & Sample ID & $\begin{array}{c}\text { Tritium } \\
\text { (pCi/ml) }\end{array}$ & $\begin{array}{c}\text { Sample } \\
\text { Date }\end{array}$ & Sample ID & $\begin{array}{c}\text { Tritium } \\
\text { (pCi/ml) }\end{array}$ \\
\hline Dec-92 & FMC001H & 55 & Dec-94 & FMC002H & 113 \\
\hline Dec-92 & FMC001F & 455 & May-95 & FMC001F & 643 \\
\hline Dec-92 & FMC002H & 2050 & May-95 & FMC001H & 63 \\
\hline Apr-93 & FMC001H & 47 & May-95 & FMC002H & 97 \\
\hline Apr-93 & FMC001F & 425 & Mar-96 & FMC001F & 138 \\
\hline Apr-93 & FMC002H & 104 & Mar-96 & FMC001H & 34 \\
\hline Sep-93 & FMC001H & 41 & Mar-96 & FMC002H & 65 \\
\hline Sep-93 & FMC002H & 105 & Sep-96 & FMC001F & 520 \\
\hline Sep-93 & FMC001F & 503 & Sep-96 & FMC001H & 35 \\
\hline Dec-93 & FMC001H & 37 & Sep-96 & FMC002H & 76 \\
\hline Dec-93 & FMC001F & 567 & Mar-97 & FMC001F & 329 \\
\hline Dec-93 & FMC002H & 145 & Mar-97 & FMC001H & 9 \\
\hline Mar-94 & FMC001H & 34 & Mar-97 & FMC002H & 78 \\
\hline Mar-94 & FMC001F & 375 & Sep-97 & FMC001F & 577 \\
\hline Mar-94 & FMC002H & 91 & Sep-97 & FMC001H & 16 \\
\hline Jun-94 & FMC001F & 331 & Sep-97 & FMC002H & 61 \\
\hline Jun-94 & FMC001H & 42 & Mar-98 & FMC001F & 39 \\
\hline Jun-94 & FMC002H & 82 & Mar-98 & FMC001H & 3 \\
\hline Sep-94 & FMC001F & 567 & Mar-98 & FMC002H & 34 \\
\hline Sep-94 & FMC001H & 52 & Aug-98 & FMC001F & 256 \\
\hline Sep-94 & FMC002H & 93 & Aug-98 & FMC001H & 25 \\
\hline Dec-94 & FMC001F & 312 & Aug-98 & FMC002H & 48 \\
\hline Dec-94 & FMC001H & 59 & & \\
\hline
\end{tabular}


Results of the Tritium Survey in the F and $\mathrm{H}$ Area Seeplines and Fourmile Branch

at SRS: March 1998 and August 1998 Sampling Events and 1989-1998 Summary

Table 11. Sample Collection Summary for F-Area Seepline Locations 1989-1998

\begin{tabular}{|c|c|c|c|c|c|c|c|c|c|c|c|c|c|c|c|c|c|c|c|}
\hline \multirow{2}{*}{$\begin{array}{l}\text { Sample } \\
\text { ID }\end{array}$} & \multirow[b]{2}{*}{ Aug-98 } & \multicolumn{18}{|c|}{ Sample Date } \\
\hline & & Mar-98 & Sep-97 & Mar-97 & Sep-96 & Mar-96 & May-95 & Dec-94 & Sep-94 & Jun-94 & Mar-94 & Dec-93 & Sep-93 & Jun-93 & Apr-93 & Dec-92 & Sep-92 & May-92 & Mar-89 \\
\hline FSP002 & $\bar{x}$ & $\mathrm{X}$ & $\mathrm{X}$ & $\mathrm{X}$ & $X$ & $\mathrm{X}$ & $X$ & $\mathrm{X}$ & $\mathrm{X}$ & $\mathrm{X}$ & $\bar{X}$ & $\mathrm{X}$ & $\mathrm{X}$ & $\mathrm{X}$ & $\mathrm{X}$ & $\mathrm{X}$ & $X$ & $\bar{X}$ & $\mathrm{X}$ \\
\hline FSP007 & $\mathrm{X}$ & $\mathrm{X}$ & $\mathrm{X}$ & $\mathrm{X}$ & $\mathrm{X}$ & $\mathrm{X}$ & $X$ & $\mathrm{X}$ & $\mathrm{X}$ & $X$ & $X$ & $X$ & $X$ & $X$ & $X$ & $X$ & $X$ & $x$ & $X$ \\
\hline FSP012 & $\mathrm{X}$ & $\mathrm{X}$ & $\mathrm{X}$ & $\mathrm{X}$ & $\mathrm{X}$ & $\mathrm{X}$ & $\mathrm{X}$ & $\mathrm{X}$ & $\mathrm{X}$ & $\mathrm{X}$ & $\mathrm{X}$ & $\mathrm{X}$ & $\mathrm{X}$ & $\mathrm{X}$ & $\mathrm{X}$ & $\mathrm{X}$ & $\mathrm{x}$ & $\mathrm{X}$ & $\mathrm{X}$ \\
\hline FSP014 & $\mathrm{X}$ & $\mathrm{X}$ & dry & $X$ & $\mathrm{X}$ & $X$ & $X$ & $\mathrm{X}$ & $\mathrm{X}$ & $X$ & $\mathrm{X}$ & $\mathrm{X}$ & $\mathrm{X}$ & $\mathrm{X}$ & $x$ & $\mathrm{X}$ & $\mathrm{X}$ & $\mathrm{X}$ & $\mathrm{X}$ \\
\hline FSP019 & $\mathrm{X}$ & $\mathrm{X}$ & $\mathrm{X}$ & $\mathrm{X}$ & $\mathrm{X}$ & $X$ & $X$ & $\mathrm{X}$ & $\mathrm{X}$ & $\mathrm{X}$ & $X$ & $X$ & $\mathrm{X}$ & $\mathrm{X}$ & $\mathrm{X}$ & $\mathrm{X}$ & $\mathrm{X}$ & $\mathrm{X}$ & $\mathrm{X}$ \\
\hline FSP026 & dry & $\mathrm{X}$ & $X$ & $\mathrm{X}$ & $X$ & $\mathrm{X}$ & $X$ & $X$ & $\mathrm{X}$ & $\mathrm{X}$ & $\mathrm{X}$ & $\mathrm{X}$ & $\mathrm{X}$ & $\mathrm{X}$ & $\mathrm{X}$ & $\mathrm{X}$ & $\mathrm{X}$ & $\mathrm{X}$ & $\mathrm{X}$ \\
\hline FSP032 & $\mathrm{X}$ & $X$ & dry & $X$ & $X$ & $X$ & $\mathrm{X}$ & $\mathrm{X}$ & $X$ & $X$ & $X$ & $X$ & $X$ & $X$ & $X$ & $X$ & $X$ & $\mathrm{X}$ & $X$ \\
\hline FSP034 & $\mathrm{X}$ & $X$ & dry & $\mathrm{X}$ & $X$ & $X$ & $X$ & $X$ & $X$ & $X$ & $x$ & $X$ & $X$ & $\mathrm{X}$ & $X$ & $X$ & $X$ & $X$ & $X$ \\
\hline FSP035 & $X$ & $X$ & $X$ & $X$ & $X$ & $X$ & $X$ & $\mathrm{X}$ & $\mathrm{X}$ & $\mathrm{X}$ & $X$ & $\mathrm{X}$ & $X$ & $X$ & $X$ & $\mathrm{X}$ & $X$ & $X$ & $\mathrm{X}$ \\
\hline FSP040 & $\mathrm{X}$ & $X$ & $X$ & $X$ & $X$ & $X$ & $X$ & $X$ & $X$ & $X$ & $x$ & $X$ & $X$ & $X$ & $X$ & $X$ & $X$ & $X$ & $X$ \\
\hline FSP047 & $\mathrm{X}$ & $X$ & $\mathrm{X}$ & $X$ & $\mathrm{X}$ & $X$ & $\mathrm{X}$ & $X$ & $\mathrm{X}$ & $X$ & $X$ & $\mathrm{X}$ & $X$ & $\mathbf{X}$ & $X$ & $X$ & $\mathrm{X}$ & $X$ & $\mathrm{X}$ \\
\hline FSP056 & dry & $x$ & $x$ & $\mathrm{X}$ & $X$ & $X$ & $x$ & $X$ & $\mathrm{X}$ & $\mathrm{X}$ & $X$ & $\mathrm{X}$ & $\mathrm{X}$ & $\mathrm{X}$ & $X$ & $X$ & $\mathrm{X}$ & $X$ & $X$ \\
\hline FSP204 & $\mathrm{X}$ & $\mathrm{X}$ & $\mathrm{X}$ & $\mathrm{X}$ & $X$ & $\mathrm{X}$ & $\mathrm{X}$ & $\mathrm{X}$ & $\mathrm{X}$ & $\mathrm{X}$ & $\mathrm{X}$ & $\mathrm{X}$ & $\mathrm{X}$ & $\mathrm{X}$ & $\mathrm{X}$ & $\mathrm{X}$ & $x$ & $\mathrm{X}$ & $\mathrm{X}$ \\
\hline FSP213 & $\mathrm{X}$ & $x$ & $X$ & $X$ & $X$ & $\mathrm{X}$ & $X$ & $X$ & $X$ & $X$ & $X$ & $X$ & $X$ & $X$ & $X$ & $X$ & $X$ & $X$ & $X$ \\
\hline FSP220 & dry & $X$ & $X$ & $\mathrm{X}$ & $\mathrm{x}$ & $\mathrm{X}$ & $\mathrm{X}$ & $x$ & $\mathrm{X}$ & $\mathrm{X}$ & $\mathrm{X}$ & $X$ & $X$ & $X$ & $X$ & $\mathrm{X}$ & $x$ & $X$ & $x$ \\
\hline FSP226 & dry & $\mathrm{X}$ & $X$ & $X$ & $X$ & $\mathrm{X}$ & dry & $X$ & $\mathrm{X}$ & $\mathrm{X}$ & $X$ & $X$ & $\mathrm{X}$ & $X$ & $X$ & $\mathrm{X}$ & $X$ & $X$ & $\mathrm{X}$ \\
\hline FSP235 & dry & $x$ & dry & $\mathrm{X}$ & $X$ & $X$ & $\mathrm{X}$ & $X$ & $\mathrm{X}$ & $X$ & $X$ & $x$ & $\mathrm{X}$ & $X$ & $X$ & $\mathrm{X}$ & $X$ & $X$ & $\mathrm{X}$ \\
\hline FSP241 & $X$ & $X$ & $X$ & $X$ & $X$ & $x$ & $X$ & $X$ & $X$ & $X$ & $X$ & $X$ & $x$ & $x$ & $X$ & $x$ & $x$ & $X$ & $X$ \\
\hline FSP249 & $\mathrm{X}$ & $\mathrm{X}$ & $\mathrm{X}$ & $X$ & $X$ & $\mathrm{X}$ & $X$ & $\mathrm{X}$ & $\mathrm{X}$ & $X$ & $X$ & $X$ & $x$ & $\mathrm{X}$ & $\mathrm{X}$ & $X$ & $X$ & $X$ & $\mathrm{X}$ \\
\hline FSP256 & $\mathrm{X}$ & $\mathrm{X}$ & $X$ & $X$ & $\mathrm{X}$ & $X$ & $\mathrm{X}$ & $X$ & $X$ & $X$ & $X$ & $X$ & $X$ & $X$ & $X$ & $X$ & $X$ & $X$ & $X$ \\
\hline FSP270 & $\mathrm{X}$ & $\mathrm{X}$ & $X$ & $X$ & $X$ & $\mathrm{X}$ & $\mathrm{X}$ & $X$ & $X$ & $X$ & $\mathrm{X}$ & $X$ & $\mathrm{X}$ & $X$ & $X$ & $X$ & $X$ & $X$ & $X$ \\
\hline FSP290 & $X$ & $\mathrm{X}$ & $X$ & $X$ & $\mathrm{X}$ & $\mathrm{X}$ & $\mathrm{X}$ & $\mathrm{X}$ & $X$ & $\mathrm{X}$ & $\mathrm{X}$ & $\mathrm{X}$ & $\mathrm{X}$ & $X$ & $\mathrm{X}$ & $X$ & $X$ & $\mathrm{X}$ & $\mathrm{X}$ \\
\hline
\end{tabular}


WSRC-TR-99-00028

Table 12. Sample Collection Summary for H-Area Seepline Locations 1989-1998

\begin{tabular}{|c|c|c|c|c|c|c|c|c|c|c|c|c|c|c|c|c|c|c|c|}
\hline \multirow{2}{*}{$\begin{array}{l}\text { Sample } \\
\text { ID }\end{array}$} & \multirow[b]{2}{*}{ Aug-98 } & \multirow[b]{2}{*}{ Mar-98 } & \multirow[b]{2}{*}{ Sep-97 } & \multirow[b]{2}{*}{ Mar-97 } & \multirow[b]{2}{*}{ Sep-96 } & \multirow[b]{2}{*}{ Mar-96 } & \multirow[b]{2}{*}{ May-95 } & \multirow[b]{2}{*}{ Dec-94 } & \multirow[b]{2}{*}{ Sep-94 } & \multirow[b]{2}{*}{ Jun-94 } & \multicolumn{2}{|c|}{ Sample Date } & \multirow[b]{2}{*}{ Sep-93 } & \multirow[b]{2}{*}{ Jun-93 } & \multirow[b]{2}{*}{ Apr-93 } & \multirow[b]{2}{*}{ Dec-92 } & \multirow[b]{2}{*}{ Sep-92 } & \multirow[b]{2}{*}{ May-92 } & \multirow[b]{2}{*}{ Mar-89 } \\
\hline & & & & & & & & & & & Mar-94 & Dec-93 & & & & & & & \\
\hline HSP003 & $x$ & $\bar{X}$ & dry & $\bar{X}$ & $\bar{X}$ & $\bar{X}$ & $\bar{X}$ & $\bar{x}$ & $\bar{X}$ & $\mathrm{X}$ & $\bar{X}$ & $\mathrm{X}$ & $\bar{X}$ & $\bar{X}$ & $\bar{X}$ & $\bar{X}$ & $\mathrm{X}$ & $\mathrm{X}$ & $\mathrm{X}$ \\
\hline HSP004 & $\mathrm{X}$ & $X$ & dry & $\mathrm{X}$ & $\mathrm{X}$ & $X$ & $X$ & $\mathrm{X}$ & $\mathrm{X}$ & $X$ & $\mathrm{X}$ & $X$ & $\mathrm{X}$ & $\mathrm{X}$ & $\mathrm{X}$ & $\mathrm{X}$ & $\mathrm{X}$ & $X$ & $\mathrm{X}$ \\
\hline HSP008 & $X$ & $\mathrm{X}$ & $\mathrm{X}$ & $X$ & $\mathrm{X}$ & $X$ & $X$ & $\mathrm{X}$ & $X$ & $\mathrm{X}$ & $\mathrm{X}$ & $X$ & $X$ & $x$ & $X$ & $\mathrm{X}$ & $X$ & $X$ & $X$ \\
\hline HSP011 & dry & $\mathrm{X}$ & dry & $\mathrm{X}$ & dry & $x$ & $\mathrm{X}$ & $\mathrm{x}$ & $\mathrm{X}$ & $\mathrm{X}$ & $X$ & $\mathrm{X}$ & $\mathrm{X}$ & $\mathrm{X}$ & $x$ & $\mathrm{X}$ & $\mathrm{x}$ & $\mathrm{x}$ & $\mathrm{X}$ \\
\hline HSP013 & $X$ & $X$ & $\mathrm{X}$ & $\mathrm{X}$ & $x$ & $\mathrm{X}$ & $X$ & $\mathrm{X}$ & $\mathrm{X}$ & $\mathrm{X}$ & $X$ & $X$ & $\mathrm{X}$ & $\mathrm{X}$ & $X$ & $\mathrm{x}$ & $\mathrm{X}$ & $\mathrm{X}$ & $X$ \\
\hline HSP015 & dry & $X$ & $X$ & $X$ & $\mathrm{X}$ & $X$ & $X$ & $X$ & $\mathrm{X}$ & $X$ & $X$ & $X$ & $X$ & $X$ & $X$ & $X$ & $X$ & $X$ & $X$ \\
\hline HSP020 & $\mathrm{X}$ & $X$ & dry & $X$ & $X$ & $X$ & $\mathrm{X}$ & $X$ & $X$ & $X$ & $\mathrm{X}$ & $X$ & $X$ & $X$ & $X$ & $x$ & $X$ & $X$ & $X$ \\
\hline HSP02S & $X$ & $X$ & $X$ & $X$ & $X$ & $X$ & dry & $X$ & $X$ & $X$ & $X$ & $X$ & $X$ & $X$ & $X$ & $x$ & $\mathrm{X}$ & $X$ & $x$ \\
\hline HSP029 & $X$ & $X$ & $X$ & $X$ & $X$ & $X$ & $X$ & $X$ & $X$ & $X$ & $X$ & $X$ & $X$ & $X$ & $X$ & $X$ & $X$ & $X$ & $X$ \\
\hline HSP034 & dry & dry & dry & dry & dry & $X$ & dry & $X$ & $X$ & $X$ & $X$ & $X$ & $X$ & $X$ & $X$ & $X$ & $X$ & $X$ & $X$ \\
\hline HSP038 & dry & dry & dry & dry & dry & dry & $X$ & $X$ & $X$ & $X$ & $X$ & $X$ & $X$ & $X$ & $X$ & $x$ & $X$ & $X$ & $X$ \\
\hline HSP043 & $X$ & $X$ & dry & $X$ & dry & $X$ & dry & $X$ & $X$ & $\mathrm{X}$ & $X$ & $X$ & $\mathrm{X}$ & $X$ & $X$ & $X$ & $X$ & $X$ & $X$ \\
\hline HSP046 & dry & $\mathrm{X}$ & dry & $X$ & $X$ & $x$ & $x$ & $X$ & $X$ & $X$ & $X$ & $X$ & $X$ & $X$ & $X$ & $X$ & $\mathrm{X}$ & $X$ & $X$ \\
\hline HSP049 & dry & $\mathrm{X}$ & $X$ & $X$ & $\mathrm{X}$ & $\mathrm{X}$ & dry & $X$ & $X$ & $X$ & $X$ & $X$ & $X$ & $X$ & $X$ & $X$ & $X$ & $X$ & $X$ \\
\hline HSP052 & $X$ & $X$ & $X$ & $X$ & $X$ & $X$ & $X$ & $X$ & $X$ & $X$ & $X$ & $X$ & $X$ & $X$ & $X$ & $X$ & $X$ & $X$ & $X$ \\
\hline HSP057 & $X$ & $X$ & dry & $\mathrm{X}$ & $X$ & $X$ & $X$ & $X$ & $X$ & $X$ & $X$ & $X$ & $X$ & $X$ & $X$ & $X$ & $X$ & $X$ & $X$ \\
\hline HSP060 & $\mathrm{X}$ & $\mathrm{X}$ & dry & $X$ & $\mathrm{X}$ & $X$ & $X$ & $X$ & dry & $\mathrm{X}$ & $X$ & $X$ & $X$ & $X$ & $\mathrm{X}$ & $X$ & $\mathrm{X}$ & $\mathrm{X}$ & $X$ \\
\hline HSP064 & $X$ & $X$ & dry & $X$ & $X$ & $X$ & $X$ & $X$ & $X$ & $X$ & $\mathrm{X}$ & $X$ & $X$ & $X$ & $x$ & $X$ & $X$ & $X$ & $X$ \\
\hline HSP071 & $X$ & $X$ & $X$ & $X$ & $X$ & $X$ & $X$ & $X$ & $X$ & $X$ & $X$ & $X$ & $X$ & $X$ & $X$ & $X$ & $X$ & $X$ & $X$ \\
\hline HSP076 & $X$ & $X$ & $\mathrm{X}$ & $X$ & $X$ & $\mathrm{X}$ & $\mathrm{X}$ & $X$ & $X$ & $X$ & $X$ & $\mathrm{X}$ & $X$ & $X$ & $X$ & $X$ & $X$ & $X$ & $X$ \\
\hline HSP097 & $X$ & $X$ & $X$ & $\mathrm{X}$ & $X$ & $X$ & $X$ & $X$ & $X$ & $X$ & $X$ & $X$ & $X$ & - $\mathrm{X}$ & $X$ & $X$ & $X$ & $X$ & $X$ \\
\hline HSP103 & $X$ & $\mathrm{X}$ & $X$ & $X$ & $X$ & $x$ & $X$ & $\mathrm{X}$ & $\mathrm{X}$ & $\mathrm{X}$ & $\mathrm{X}$ & $\mathrm{X}$ & $\mathrm{X}$ & $\mathrm{X}$ & $\mathrm{X}$ & $\mathrm{X}$ & $\mathrm{X}$ & $x$ & $\mathrm{X}$ \\
\hline
\end{tabular}


Results of the Tritium Survey in the F and $H$ Area Seeplines and Fourmile Branch

at SRS: March 1998 and August 1998 Sampling Events and 1989-1998 Summary

Table 13. Sample Collection Summary for 643-E Seepline Locations 1992-1998

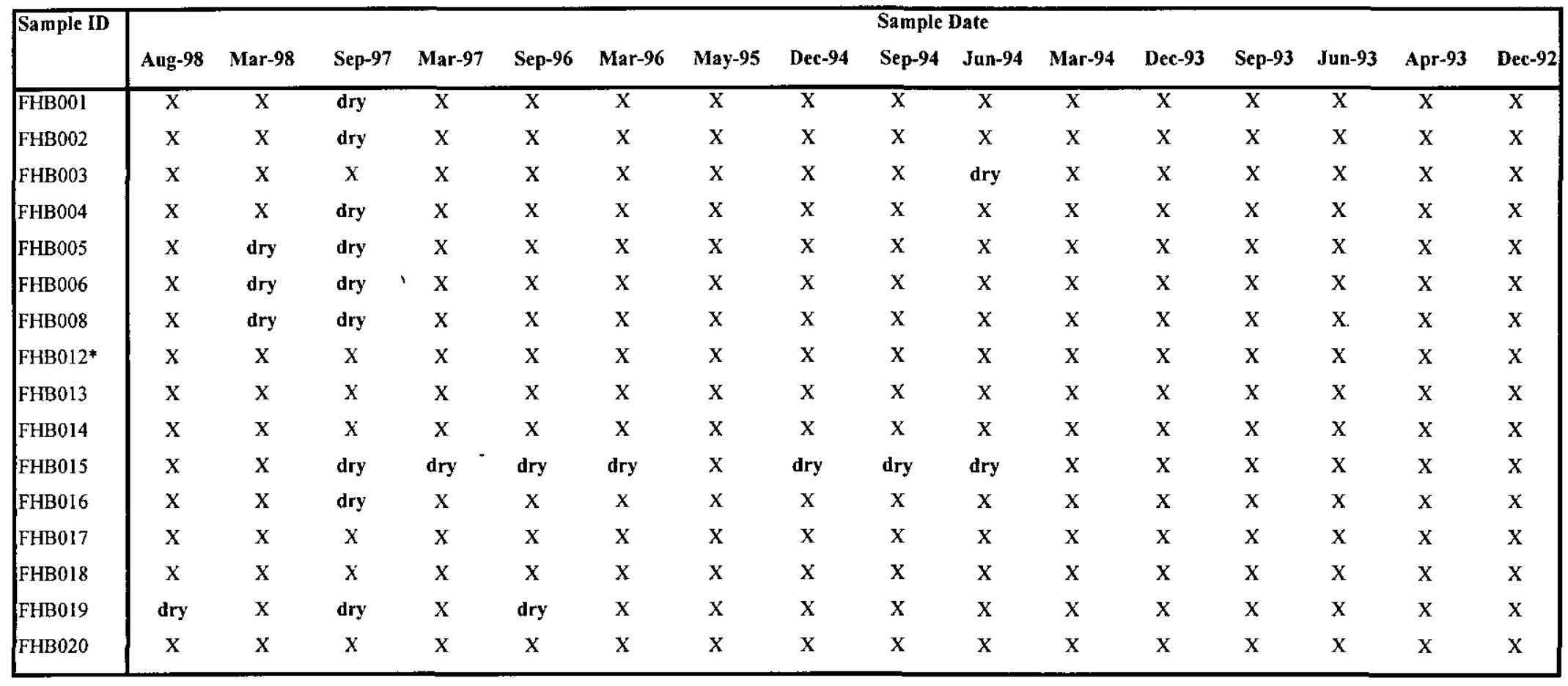

